\title{
A Bipartite Geminivirus with a Highly Divergent Genomic Organization Identified in Olive Trees May Represent a Novel Evolutionary Direction in the Family Geminiviridae
}

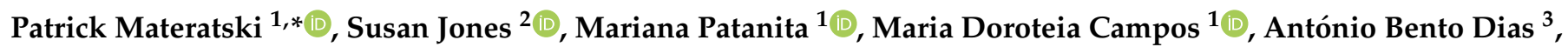 \\ Maria do Rosário Félix ${ }^{4}$ and Carla M. R. Varanda ${ }^{1}$ (B) \\ 1 MED—Mediterranean Institute for Agriculture, Environment and Development, Instituto de Investigação e \\ Formação Avançada, Universidade de Évora, Pólo da Mitra, Ap. 94, 7006-554 Évora, Portugal; \\ mpatanita@uevora.pt (M.P.); mdcc@uevora.pt (M.D.C.); carlavaranda@uevora.pt (C.M.R.V.) \\ 2 Information and Computational Science Department, The James Hutton Institute, Dundee DD2 5DA, UK; \\ sue.jones@hutton.ac.uk \\ 3 MED—Mediterranean Institute for Agriculture, Environment and Development \& Departamento de \\ Engenharia Rural, Escola de Ciências e Tecnologia, Universidade de Évora, Pólo da Mitra, Ap. 94, \\ 7006-554 Évora, Portugal; adias@uevora.pt \\ 4 MED—Mediterranean Institute for Agriculture, Environment and Development \& Departamento de \\ Fitotecnia, Escola de Ciências e Tecnologia, Universidade de Évora, Pólo da Mitra, Ap. 94, \\ 7006-554 Évora, Portugal; mrff@uevora.pt \\ * Correspondence: pmateratski@uevora.pt
}

\section{check for} updates

Citation: Materatski, P.; Jones, S.; Patanita, M.; Campos, M.D.; Dias, A.B.; Félix, M.d.R.; Varanda, C.M.R. A Bipartite Geminivirus with a Highly Divergent Genomic Organization Identified in Olive Trees May Represent a Novel Evolutionary Direction in the Family Geminiviridae. Viruses 2021, 13, 2035. https:// doi.org/10.3390/v13102035

Academic Editor: Solomon Maina

Received: 9 September 2021

Accepted: 6 October 2021

Published: 9 October 2021

Publisher's Note: MDPI stays neutral with regard to jurisdictional claims in published maps and institutional affiliations.

Copyright: (c) 2021 by the authors. Licensee MDPI, Basel, Switzerland. This article is an open access article distributed under the terms and conditions of the Creative Commons Attribution (CC BY) license (https:/ / creativecommons.org/licenses/by/ $4.0 /)$.
Abstract: Olea europaea Geminivirus (OEGV) was recently identified in olive in Italy through HTS In this work, we used HTS to show the presence of an OEGV isolate in Portuguese olive trees and suggest the evolution direction of OEGV. The bipartite genome (DNA-A and DNA-B) of the OEGV-PT is similar to Old World begomoviruses in length, but it lacks a pre-coat protein (AV2), which is a typical feature of New World begomoviruses (NW). DNA-A genome organization is closer to NW, containing four ORFs; three in complementary-sense AC1/Rep, AC2/TrAP, AC3/REn and one in virion-sense $\mathrm{AV} 1 / \mathrm{CP}$, but no AC4, typical of begomoviruses. DNA-B comprises two ORFs; MP in virion sense with higher similarity to the tyrosine phosphorylation site of NW, but in opposite sense to begomoviruses; BC1, with no known conserved domains in the complementary sense and no NSP typical of bipartite begomoviruses. Our results show that OEGV presents the longest common region among the begomoviruses, and the TATA box and four replication-associated iterons in a completely new arrangement. We propose two new putative conserved regions for the geminiviruses CP. Lastly, we highlight unique features that may represent a new evolutionary direction for geminiviruses and suggest that OEGV-PT evolution may have occurred from an ancient OW monopartite Begomovirus that lost V2 and C4, gaining functions on cell-to-cell movement by acquiring a DNA-B component.

Keywords: high-throughput sequencing; Olea europaea L.; Geminiviridae; recombination; evolution

\section{Introduction}

Olive (Olea europaea L.) is one of the most cultivated fruit crops around the world and has significant environmental, social and landscape impact in many countries such as Portugal. Olive trees are known to be infected by 17 different viruses [1-9]. A common feature of olive viruses is the difficulty of associating viral presence to symptoms. Some authors have associated viral symptoms with chlorosis, defoliation, bumpy fruits, reduction of yield and oil quality $[10,11]$, however, most viruses, have been recovered from trees without apparent symptoms [7,10,12]. Nevertheless, despite the difficulty in associating viruses to symptoms, many olive viruses are easily transmitted to other hosts and olive propagative material must be free of viruses for certification and commercialization. For these reasons, studies of the olive virome in different countries is of great economic importance. 
OEGV (Olea europaea geminivirus) is the most recently identified virus in olive [8]. It was identified in olive trees in Italy using high-throughput sequencing (HTS) and belongs to the family Geminiviridae that is the largest family of plant viruses alongside the family Potyviridae. Members from the family Geminiviridae are present in tropical and subtropical regions and constitute over 520 distinct species $[13,14]$. Geminiviruses have either one or two circular single-stranded DNA (ssDNA), with approximately $2.7-5.2 \mathrm{~kb}$, encapsidated into geminate icosahedral virions [15]. Very recently, this family increased from nine recognized genera: Becurtovirus, Begomovirus, Capulavirus, Curtovirus, Eragrovirus, Grablovirus, Mastrevirus, Topocuvirus, Turncurtovirus to 14 genera [16], with Citlodavirus, Maldovirus, Mulcrilevirus, Opunvirus and Topilevirus being added. Besides these genera, there are still a number of divergent geminivirus species that have not yet been assigned to any genus $[8,17]$. HTS technologies have contributed to the recent extension of the Geminiviridae family and increased our understanding of the evolutionary history of this family.

Genera Begomovirus and Mastrevirus correspond to $94 \%$ of the Geminiviridae virus species, although Begomovirus is by far the genus with the highest number of recognized species, over 445 [16]. This remarkable success, in the higher number of species, can be attributed to many features including high prevalence of the virus vector Bemisia tabaci in monocultures worldwide and infection of non-cultivated plants. In addition, these viruses have the capacity to rapidly evolve via pseudo- and recombination, mutation and acquisition of new DNA components and satellites [18-20]. Begomoviruses are classified into two main lineages, Old World (OW: Eurasia, Africa and Oceania) and New World (NW: the Americas). Most NW Begomovirus are bipartite, comprising DNA-A and DNAB, with a few monopartite reported exceptions [21,22]. The DNA-A of bipartite NW begomoviruses has five open reading frames (ORFs), one in the virion-sense encoding the coat protein (AV1 or $\mathrm{CP}$ ) and four in the complementary sense encoding the replication initiation protein ( $\mathrm{AC} 1$ or Rep), the transcriptional activator (AC2 or TrAP), the replication enhancer (AC3 or REn) and the AC4 protein (or C4) $[15,23]$. The DNA-B of bipartite NW begomoviruses comprises two ORFs; one in the virion-sense encoding the nuclear shuttle protein (BV1 or NSP); one in the complementary sense encoding the movement protein (BC1 or MP) [19,24]. In contrast with the NW begomoviruses, the majority of OW begomoviruses are monopartite with their DNA comprising 6 ORFs, presenting an additional ORF V2 or AV2, also referred as pre-coat [25], and that is not present in NW begomoviruses. It was believed that NW Begomovirus appeared more recently than OW Begomovirus, after continental separation in the Cenozoic era [26], however, some studies have provided evidence of the NW Begomoviruses' presence in the Old World, prior to continental separation [27].

DNA-A and DNA-B of begomoviruses are very different in terms of nucleotide sequence, except in part of the intergenic region (IR) segment ( 180 nt) known as "common region" (CR). Inside the CR, they present an origin of replication (Ori), that includes a stemloop structure $(\sim 30 \mathrm{nt})$ containing a nonanucleotide sequence $\left(5^{\prime}\right.$-TAATATTAC- $\left.3^{\prime}\right)$ typical of most Geminiviridae and conserved iterative sequences (iterons). These bidirectional iterative sequences ( $5-8 \mathrm{nt}$ in length) are required for specific recognition and binding by Rep during replication [28-30]. The T-A site within the conserved nonanucleotide sequence is necessary during replication for cleaving and joining viral DNA. Together, the conserved nonanucleotide and the iterons are functional targets for Rep, that recognizes and binds specifically to the iterons and subsequently introduces a nick into the nonanucleotide sequences to initiate the DNA replication by a rolling-circle (RCR) mechanism [30,31].

The remaining Geminiviridae virus species cluster into 13 genera that have exclusively monopartite genomes and differ in genome arrangement. They produce between 4 and 8 multifunctional proteins, encoded by bidirectional and partially overlapping ORFs. Functions of these proteins have mostly been determined by positional analogy to other studied proteins within the Geminiviridae and are putatively involved in a variety of functions such as encapsidation, viral movement, vector transmission, viral replication, plant cell interference, regulation of viral gene expression and suppression of host antiviral responses [15,23]. 
Members within the Geminiviridae present many mixed features among them, reinforcing that recombination is a major evolution driver within this family. For example, Becurtovirus $\mathrm{CP}$ is Curtovirus-like whereas the Rep is most related to that of Mastrevirus. Eragrovirus C2 is a positional analog of Topocuvirus, Curtovirus and Begomovirus TrAP genes, Rep is most related to Begomovirus, Curtovirus and Topocuvirus and CP is most similar to Mastrevirus. Topocuvirus genome is similar to monopartite Begomovirus and are suggested to have diverged after a recombination event that altered vector specificity [32], originating a $\mathrm{CP}$ more closely related to Curtoviruses. Turncurtovirus have a similar genome arrangement in the complementary sense to that of Curtoviruses, however, with low sequence identity, except for $\mathrm{C} 4$.

OEGV, first identified in olive in Italy, was classified as a putative member of a new genus within the Geminiviridae family [8]. In our study, we used RNA-sequencing to identify OEGV in olive in Portugal (denoted in this paper as OEGV-PT) and we provided new evidence that OEGV-PT has genomic characteristics from both OW and NW Begomovirus. We also show that OEGV-PT presents unique features distinct from other geminiviruses and suggest that OEGV-PT evolution may have occurred from an ancient OW monopartite Begomovirus that lost V2 and C4, gaining functions on cell to cell movement by acquiring a DNA-B component.

\section{Materials and Methods}

\subsection{Sampling Protocol}

Sampling was carried out at the end of the autumn and at the beginning of the winter in 2019. Four olive oil producing sites were sampled; three in the Alentejo region, south of Portugal (sites A, B and C) and one in the Ribatejo region, center of Portugal (site D); all sites are influenced by Mediterranean climate. Sampled olive groves occupy an area of $320,000 \mathrm{~m}^{2}$ in Monforte (site A) $\left(39^{\circ} 4^{\prime} 3.99^{\prime \prime} \mathrm{N}, 7^{\circ} 28^{\prime} 13^{\prime \prime} \mathrm{W}\right), 450,000 \mathrm{~m}^{2}$ in Evora (site B) $\left(38^{\circ} 30^{\prime} 05.54^{\prime \prime} \mathrm{N}, 7^{\circ} 45^{\prime} 19.79^{\prime \prime} \mathrm{W}\right), 150.000 \mathrm{~m}^{2}$ in Safara (Site C) $\left(39^{\circ} 4^{\prime} 3.99^{\prime \prime} \mathrm{N}, 7^{\circ} 16^{\prime} 13^{\prime \prime} \mathrm{W}\right)$ and $180,000 \mathrm{~m}^{2}$ in Santarém (site D) $\left(39^{\circ} 17^{\prime} 04.81^{\prime \prime} \mathrm{N}, 8^{\circ} 41^{\prime} 24.99^{\prime \prime} \mathrm{W}\right)$. The olive trees were 10-30 years old, produced under intensive regime (planted with a spacing of $7 \times 5 \mathrm{~m}$ ), or super intensive regime (planted with a spacing of $4 \times 1.35 \mathrm{~m}$ ) and belonged to four different cultivars (Galega vulgar, Cobrançosa, Picual and Arbequina). At each site, 10 olive trees of each cultivar (10 trees $\times 4$ cultivars) were randomly sampled. Each sample consisted of 10 3-year stems cut from each plant around the whole tree at a height of $1.5 \mathrm{~m}$ above ground. All sites received programmed applications of phytosanitary treatments such as fungicides; benzimidazole or MBC, demethylation inhibitor (DMI), strobilurin, copper hydroxide and copper oxychloride, and insecticides; lambda-cyhalothrin, dimethoate and deltamethrin. A total of 160 trees were sampled ( 4 sites $\times 4$ cultivars $\times 10$ trees). Samples were transported to the laboratory in a refrigerated basket, stored at $4{ }^{\circ} \mathrm{C}$ and processed within the next $24 \mathrm{~h}$. Cortical scrapings of the 3-year stems of each sampled tree were ground in liquid nitrogen, mixed in equal amounts, combined per cultivar at each site (4 cultivars $\times 4$ sites) and stored at $-80{ }^{\circ} \mathrm{C}$.

\subsection{RNA-Extraction and Sequencing}

Total RNA of each of the 16 pooled samples was extracted and purified using Qiagen RNeasy Plant Mini kit following the manufacturer's instructions. Purified RNA was eluted in RNAse-free water and stored at $-80{ }^{\circ} \mathrm{C}$ prior to subsequent sequencing at the Fera Science Ltd. (York, UK). Purified RNAs were subtracted from the ribosomal RNA using a Ribo-Zero rRNA removal kit for plants (Illumina, San Diego, CA, USA). Subsequently, cDNA libraries were prepared using a ScriptSeq library preparation kit (Illumina) and paired-end sequencing was conducted using an Illumina MiSeq $(2 \times 300$ nt version 3$)$ machine. The controls included an uninfected tobacco leaf spiked with External RNA Control Consortium (ERCC) positive control artificial RNA. 


\subsection{Bioinformatics Analysis of RNA-Sequence Data}

Raw reads were trimmed using Trimmomatic [33] with the following parameters: LEADING:20 TRAILING:20 SLIDINGWINDOW:4:20 and a minimum read length of 30. To remove host reads, trimmed reads were mapped to the concatenated genome sequences of Olea europaea var. sylvestris (NC_036237.1) and Olive chloroplast (FN996972.1). Mapping was conducted using Bowtie2 (v2.3.4.3) ${ }^{3}$ [34] (score-min value " $\mathrm{L}, 0,-0.2^{\prime \prime}$ ). The unmapped reads, designated as non-host reads, were assembled into contigs using Trinity software $(\mathrm{v} 2.8 .4)^{4}$ [35]. Contigs $>200 \mathrm{bp}$ in length were then mapped against a database of 1,461,177 proteins, derived from 39,163 viruses with complete genomes in Genbank (v237) [36]. The mapping was conducted using DIAMOND software6 (with parameters -max-target-seqs 5 -e-values $<10-6$-subject-cover 25 -sensitive). The predicted virus sequences were then filtered at either (a) $50 \%$ protein sequence identity and $25 \%$ target protein length overlap or (b) $30 \%$ sequence identity, a $25 \%$ target overlap length at the protein level and a contig length $>1000 \mathrm{bp}$.

\subsection{DNA Extraction, PCR Validation, and Full-Length Amplification of Viral Genomic DNA Molecules}

After the identification of a DNA virus (geminivirus) sequences in the RNA-sequence results, the total DNA of each olive sample was extracted and purified using a DNeasy Plant Mini kit (Qiagen, Hilden, Germany) following the manufacturer's protocol, for the subsequently polymerase chain reaction (PCR) validation in the samples. DNA concentration was determined by using a Quawell Q9000 micro spectrophotometer (Quawell Technology, Beijing, China). First, the PCR validation was done based on the two divergent contig sequences (2727 and $1286 \mathrm{bp}$ ) mapped by HTS, using two specific pairs of primers, in addition, several PCR specific primers were designed based on the two different contigs (2727 and $1286 \mathrm{bp}$ ) to recover full-length DNAs (Table S1). The strategy was based on the inverse PCR assays to bi-directionally (due to the circular DNA) amplify the full-length DNAs. PCR reactions were performed in a total volume of $50 \mu \mathrm{L}$, containing 30-80 ng of genomic DNA, $10 \mathrm{mM}$ Tris- $\mathrm{HCl}$ (pH 8.6), $50 \mathrm{mM} \mathrm{KCl}, 1.5 \mathrm{mM} \mathrm{MgCl}_{2}, 0.2 \mathrm{mM}$ dNTPs (Fermentas, Thermo Scientific, Waltham, MA, USA), $0.2 \mu \mathrm{M}$ of each primer and $2.5 \mathrm{U}$ of DreamTaq DNA polymerase (Fermentas, Thermo Scientific, Waltham, MA, USA). Amplification reactions were carried out in a Thermal Cycler (BioRad, Hercules, CA, USA) with an initial temperature of $95^{\circ} \mathrm{C}$ for $2 \mathrm{~min}$, followed by 40 cycles of $95^{\circ} \mathrm{C}$ for $30 \mathrm{~s} ; 55^{\circ} \mathrm{C}$ for $1 \mathrm{~min}$ and $72{ }^{\circ} \mathrm{C}$ for $2 \mathrm{~min}$, as well as a final extension at $72{ }^{\circ} \mathrm{C}$ for $10 \mathrm{~min}$. Amplified products were first analyzed by electrophoresis in $1 \%$ agarose gel and then purified using DNA Clean \& Concentrator (Zymo Research, Irvine, CA, USA) according to the instructions of the manufacturer, and finally sequenced by Macrogen (Madrid, Spain) in both directions. BLAST, at the National Center for Biotechnology Information (NCBI) was used as a basic local alignment search tool to search for homologous sequences.

\subsection{Sequence and Phylogenetic Analyses}

MEGA software version 10.1.8 [37] with CLUSTAL $W$ was used for the analysis of nucleotide and amino acid sequences of OEGV-PT DNA-A and DNA-B. Sequences from 39 members, most representative of the family Geminiviridae, including some viruses that had not yet been classified into genera, were retrieved from the GenBank database (release 242.0). Virus genera, species and abbreviations, and GenBank accession numbers used are summarized in Table S2. The identification of predicted proteins encoded by each genomic DNA molecule (DNA-A and DNA-B) in OEGV, was achieved using Open Reading Frame (ORF) Finder (RRID:SCR_016643) (https://www.ncbi.nlm.nih.gov/orffinder; accessed on 6 September 2021) and the SmartBLAST algorithm at NCBI. The ProtParam program was used for determination of the theoretical isoelectric point and protein molecular mass [38]. For multiple sequence alignments (nucleotide and amino acid) the Clustal Omega alignment program (European bioinformatics Institute, EMBL-EBI) was used. Phylogenetic trees were constructed using the maximum-likelihood (ML) method based 
on the Tamura-Nei model, that showed the lowest Bayesian information criterion (BIC) score and was the best-fit nucleotide/amino acid substitution model for these data. To establish relationships between sequences according to their genetic distances the neighbor joining (NJ) model was used. The significance of the interior branches was determined through bootstrap analyses with 1000 replicates. Pairwise sequence identities of the full genome, $\mathrm{CP}$ and Rep of OEGV-PT and representatives of different geminiviruses lineages were determined using Sequence Demarcation Tool (SDT) v1.2 [39].

\subsection{Recombination Analysis}

To detect evidence of recombination in OEGV-PT, we analyzed OEGV-PT DNAA sequence together with the previously described 39 additional geminivirus genome sequences (Table S2) and DNA-B sequence with 12 other begomoviruses. Sequences were aligned with MEGA 10.1.8 [37] and recombination analysis was performed using the Recombination Detection Program (RDP4.101 Software) [40] with default settings using the detection methods RDP, GENECONV, BOOTSCAN, MaxCHI, CHIMERA, SiSCAN and 3SEQ. Only recombination events detected by three or more methods with $p$-values $<0.05$ were accepted.

\subsection{Prediction of Insect Vector through CP Analysis}

$\mathrm{CP}$ amino acid sequences were used to search for specific patterns within subgroups of viruses that shared the same type of insect vector for prediction of the putative insect vector of OEGV-PT. Protein specificity determining positions (SDPs) were determined using Speer-server [41] and SCI-PHY for automated subgrouping [42], setting the relative entropy term and physico-chemical (PC) property distance term weights to one.

\section{Results}

\subsection{RNA-Sequence Analysis}

The total number of trimmed sequences reads recovered from the 16 samples ranged from $882 \mathrm{~K}$ to 2.1 million. Olea europaea var. sylvestris (NC_036237.1) and Olive chloroplast (FN996972.1) (host reads) constituted between $42 \%$ and $55 \%$ of the trimmed reads in each olive sample. Assembling the non-host reads into contigs, gave between 743 and $21.9 \mathrm{~K}$ contigs per sample. The number of contigs $>2500 \mathrm{bp}$ length was small and ranged between 0 and 67 (Table 1). Contigs $>200$ bp in length were mapped against viral genomes in Genbank and six contigs mapped to sequences from the Geminiviridae family (Table 1). From these, two were in trees from the cultivar Galega vulgar at site C, and comprised 2727 and $2475 \mathrm{bp}$, respectively, and three were also from the cultivar Galega vulgar but at sites B (two contigs) and D (one contig) and comprised 808, 874 and $323 \mathrm{bp}$, respectively. These five contigs showed $100 \%$ identity. One remaining contig (1286 bp), also in the cultivar Galega vulgar at site C, shared only $63.6 \%$ sequence similarity to the other 5 contigs. A BlastP search against the Genbank virus genomes with the 2727 and 1286 bp length contigs, showed 100\% identity in DNA-A (accession number MW316657; 2775 bp in length) and 99.96\% identity in DNA-B (MW316658; 2763 bp in length), which both correspond to a geminivirus found in olive in Italy and named Olea europaea Geminivirus (OEGV) [8]. 
Table 1. Summary statistics of (1) raw sequence read pairs, $(2)$ trimming, $(3,4)$ host mapping and $(5,6)$ contig assembly.

\begin{tabular}{|c|c|c|c|c|c|c|c|}
\hline & & (1) & (2) & (3) & (4) & (5) & (6) \\
\hline Sites & Sample ID & $\begin{array}{c}\text { Raw } \\
\text { Reads }\end{array}$ & $\begin{array}{c}\text { Trimmed } \\
\text { Reads }\end{array}$ & $\begin{array}{c}\text { Nonhost } \\
\text { Reads }\end{array}$ & $\begin{array}{c}\text { Host } \\
\text { reAds (\%) }\end{array}$ & $\begin{array}{l}>200 \mathrm{bp} \\
\text { Contigs }\end{array}$ & $\begin{array}{c}>2500 \mathrm{bp} \\
\text { Contigs }\end{array}$ \\
\hline \multirow{4}{*}{ Site A } & GM1 & $1,439,571$ & $1,354,917$ & 718,728 & 47.0 & 3.433 & 1 \\
\hline & CM2 & $1,829,542$ & $1,734,121$ & 943,211 & 45.6 & 2.803 & 1 \\
\hline & PM3 & 882,313 & 833,859 & 479,347 & 42. 5 & 743 & 1 \\
\hline & AM4 & $1,218,856$ & $1,125,962$ & 621,743 & 44.8 & 11.968 & 5 \\
\hline \multirow{4}{*}{ Site B } & GF13 & $1,234,906$ & $1,166,501$ & 632,432 & 45.8 & 4.572 & 10 \\
\hline & CF14 & $1,567,086$ & $1,480,478$ & 786,043 & 46.9 & 5.106 & 8 \\
\hline & PF15 & $1,267,441$ & $1,197,144$ & 670,079 & 44. 0 & 4.759 & 1 \\
\hline & AF16 & $1,612,115$ & $1,527,259$ & 771,328 & 49.5 & 14.093 & 39 \\
\hline \multirow{4}{*}{ Site C } & GL9 & $1,744,076$ & $1,644,553$ & 897,574 & 45.4 & 8.116 & 23 \\
\hline & CL10 & $1,022,113$ & 953,274 & 533,379 & 44. 0 & 529 & 3 \\
\hline & PL11 & $1,897,805$ & $1,804,294$ & 883,768 & 51.0 & 21.911 & 67 \\
\hline & AL12 & $1,461,607$ & $1,376,263$ & 733,076 & 46.7 & 3.404 & 0 \\
\hline \multirow{4}{*}{ Site D } & GS5 & 825,863 & 750,849 & 43,448 & 42.1 & 3.426 & 2 \\
\hline & CS6 & $2,073,509$ & $1,974,815$ & $1,074,547$ & 45.6 & 7.887 & 5 \\
\hline & PS7 & $1,796,210$ & $1,699,435$ & 914,666 & 46. 2 & 2.667 & 1 \\
\hline & AS8 & $1,311,804$ & $1,249,506$ & 675,575 & 45.9 & 1.748 & 1 \\
\hline
\end{tabular}

\subsection{Validation of HTS Results and OEGV-PT Presence in Olive}

RNA-sequence derived results were validated through the amplification of the two different contigs (2727 and $1286 \mathrm{bp}$ ) using a pair of primers specifically designed for each contig. The recovery approach of the full-length genome of the OEGV-PT DNA (with a circular DNA) was done using the set of overlapping primers specifically designed for each of the contigs sequences and followed by inversed PCR primers assays. The full nucleotide (nt) sequencing of both contigs (2727 and $1286 \mathrm{bp}$ ) revealed two circular DNAs; of 2775 and $2763 \mathrm{bp}$, respectively, presenting the same length of OEGV genomes described by Chiumenti et al. [8]. In addition, the validation of olive samples showed that a total of 27 $(16.9 \%)$ from the 160 sampled trees were positive for OEGV-PT DNA (DNA-A and DNA-B). None of the trees sampled had typical viral symptoms. At site B a total of $8(20 \%)$ olive trees were positive; at site $C$ there were 10 positive $(25 \%)$ and at site $D$ there were 9 positive $(22.5 \%)$. All trees at site A were negative. An intriguing result was that all positive trees belonged to the cultivar Galega vulgar, suggesting a certain specificity of OEGV-PT for this cultivar, however, more robust sampling, in terms of number of trees, fields, or regions is needed to validate this observation.

\subsection{Genome Organization of OEGV-PT DNA-A and Its DNA-B Cognate Molecule}

The nucleotide (nt) similarity, size and genome organization of OEGV-PT DNA-A is identical to OEGV isolate from Italy [8]. Interestingly, and also as verified by Chiumenti et al. [8] no C4, typical of the begomoviruses, was found. The full nucleotide (nt) sequence of OEGV-PT DNA-A (2775 bp) presents a length typical of OW begomoviruses and an organization similar to NW begomoviruses. The DNA-B of OEGV-PT presents the same length $(2763 \mathrm{bp})$ and genome organization of OEGV isolate from Italy [8] but differs in a single nucleotide within the BV1/MP (Figure S1).

Based on the alignment of DNA-A and DNA-B genomic sequences (Figure 1A), the longest identical sequence segment flanking the invariant nonanucleotide sequence was considered as the common region (CR). OEGV-PT DNA-A and DNA-B share a CR of approximately $403 \mathrm{nt}(2493-121 \mathrm{nt})$, which is $99 \%$ identical, with only three polymorphisms, evidence that these are cognate components of a bipartite genome. The CR region contains a structure that has the characteristics of an inverted repeat capable of forming a stem-loop structure (Figure 1) and also harbors a highly conserved apex with invariant nonanucleotide $5^{\prime}$-TAATATT $\downarrow$ AC-3' (the Rep-nicking site), and an GC rich region close to the stem-loop 
structure was identified. In addition, there was a TATA box and four replication-associated iterative sequences "iterons"; two sites with a TGGGGA consensus upstream the TATA box and two inverted repeat sequences TCCCCA, one downstream and the other upstream from the TATA box (Figure 1A,B).

\section{A}

Common Region (CR)

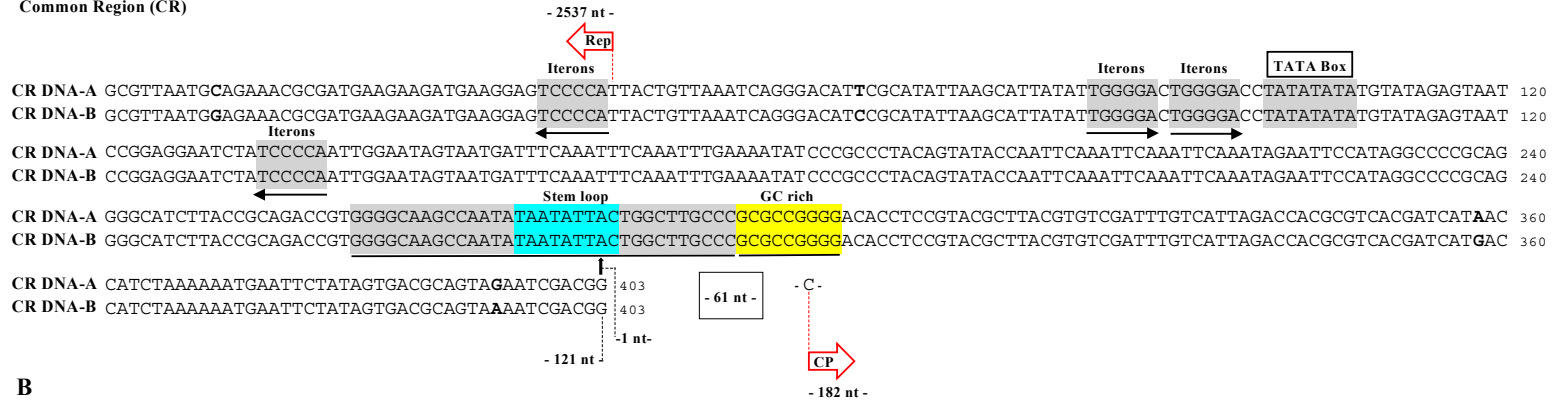

Iteron arrangement

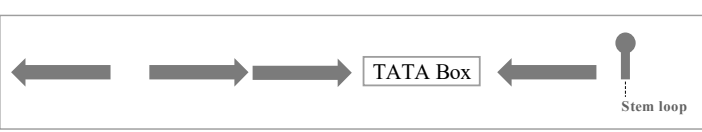

Figure 1. (A) Common region of OEGV-PT DNA-A and DNA-B alignment $\left(5^{\prime}-3^{\prime}\right)$. Iterons and complementary iterons sequences are shown in gray, black arrows indicate their relative orientation; TATA box is shown in gray; the nonanucleotide sequence is shown in blue together with the sequences with the potential to form a stem-loop structure (in gray) to the right and to the left. The differences in the nucleotide sequences between both OEGV-PT DNAs (A and B) are shown in bold. The $\downarrow$ (black arrow) indicates position 1 in the viral genome corresponding to the predicted replication origin of the viral DNA. GC rich region in shown in yellow. (B) Iterons arrangement in OEGV-PT DNA-A and DNA-B alignment $\left(5^{\prime}-3^{\prime}\right)$ positioned in relation to the TATA box and stem loop. Gray arrows indicate two iterons (virion-sense) and two complementary iterons (complement-sense).

\subsection{Phylogenetic Relationships and Pairwise Identities with Other Geminiviruses}

OEGV-PT DNA-A was shown to be 98-100\% identical to 11 full DNA-A sequences recently deposited in Genbank (Accession numbers MW316657 and MW560446 to MW560455) [43], corresponding to a geminivirus found in olive and to which the name Olea europaea Geminivirus (OEGV) was proposed [8].

OEGV-PT DNA-A pairwise and phylogenetic analysis of AC1 and AV1 predicted proteins confirms divergent results in terms of geminiviral origin as suggested by Chiumenti et al. [8] (Figure 2A). We included the analysis of $\mathrm{AC} 2$ and $\mathrm{AC} 3$ proteins, both showing to be more related to Begomovirus, as verified for AC1 (Table S3). We also included, in this analysis, a new group of NW begomoviruses, belonging to the SLCV clade with which OEGV-PT DNA-A showed the highest similarity (62.1\%). OEGV-PT full DNA-B sequence is $99.96 \%$ similar to OEGV full DNA-B from Italy (Accession number MW316658), with a single difference at nt $981, \mathrm{C}$ in the Italian and $\mathrm{T}$ in the PT isolate.

OEGV and OEGV-PT DNA-B identity to the other begomoviruses ranges from $57.1 \%$ to $60.5 \%$. The translation product of ORF BC1 (534 nt; 177 aa; $24.1 \mathrm{kDa}$ ) showed no resemblance in the blastP analysis. The translation product of ORF BV1 (891 nt; 296 aa; $34.5 \mathrm{kDa}$ ) is related to Begomovirus BC1.

The translation product of ORF AC1 (1.095 nt; 364 aa; $14.6 \mathrm{kDa})$ is related to the Rep (ORF AC1) of Begomovirus. Pairwise identities showed that the highest OEGV-PT Rep identities $(>50 \%)$ were found with those of the genera Begomovirus, Curtovirus, Turncurtovirus, Topocuvirus, which cluster together with OEGV-PT (I), as revealed by the phylogenetic analysis of the Rep of geminiviruses (Figure 2B). Four other clusters are composed by genera that present lower Rep identities to OEGV-PT; one cluster contains Capulavirus (II); other Mastrevirus (III); other Grablovirus (IV) and the other Becurtovirus and Citlodavirus and the unassigned MMDAV0 (V). 
A

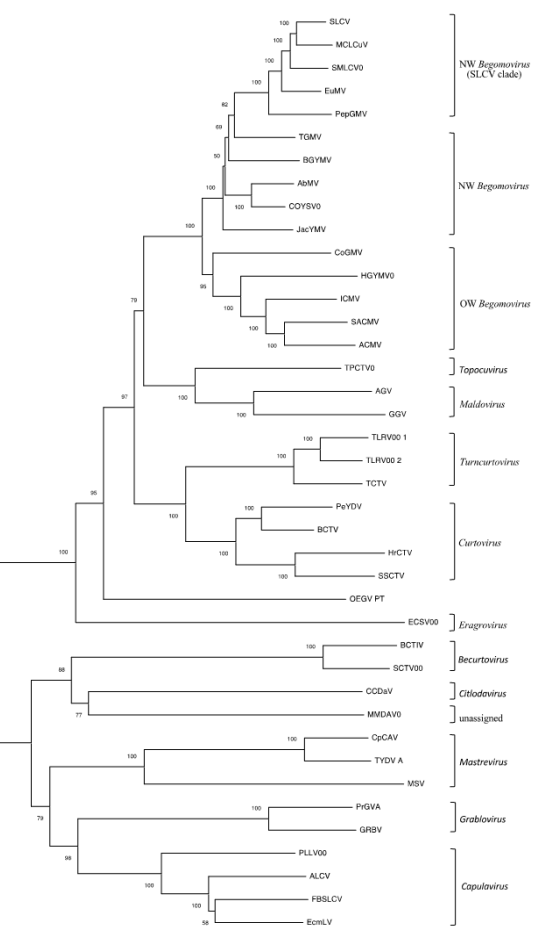

B

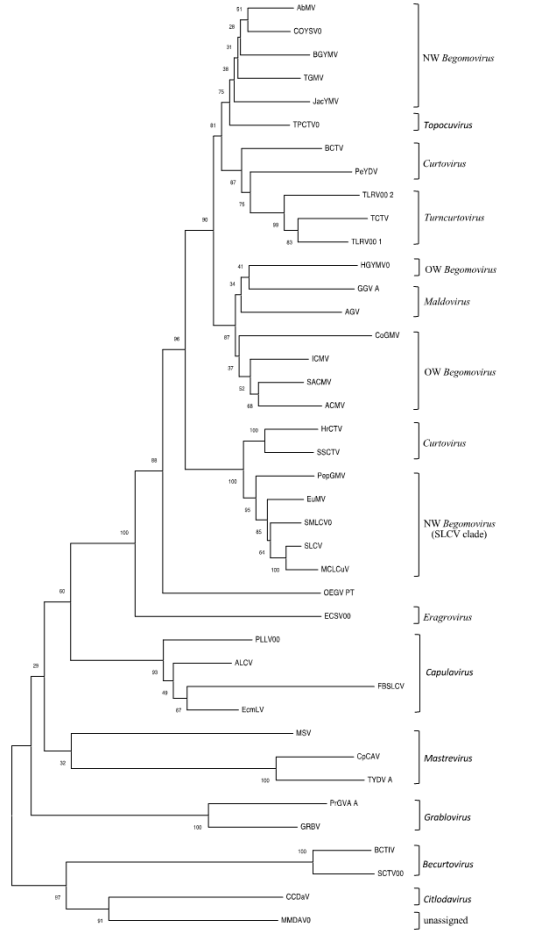

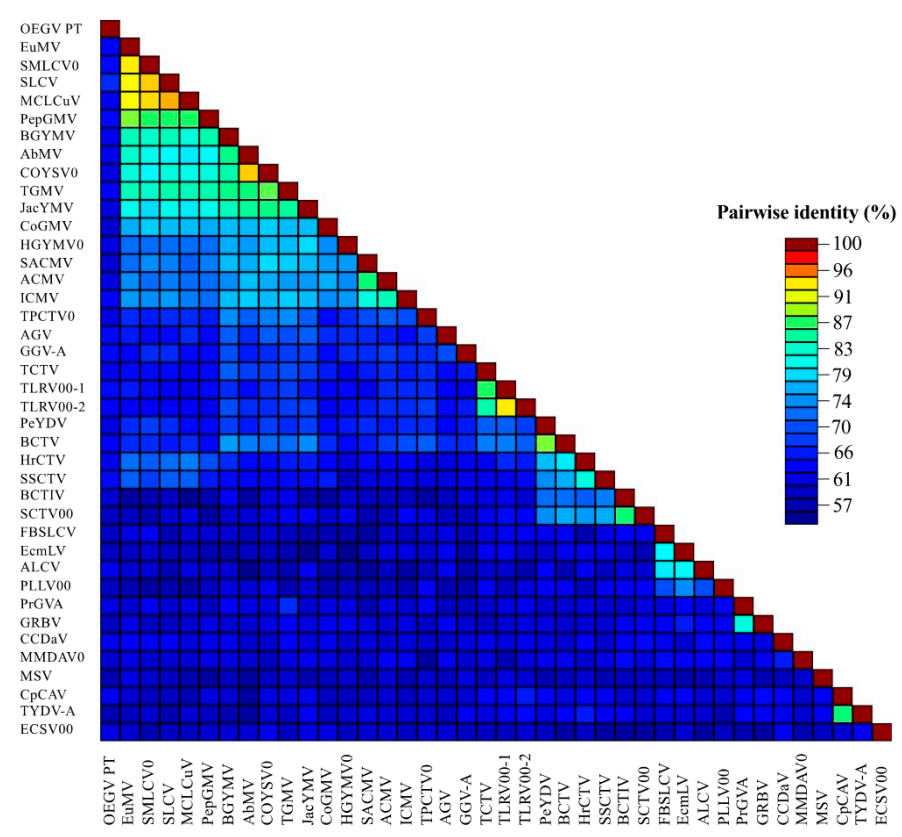

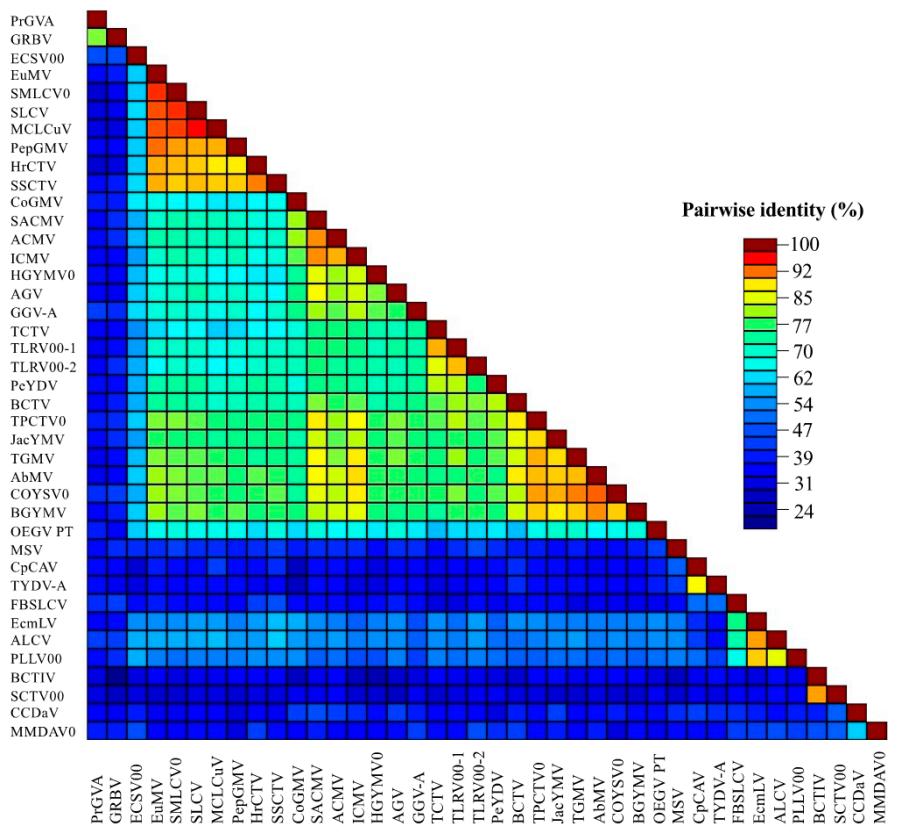

Figure 2. Cont. 
C

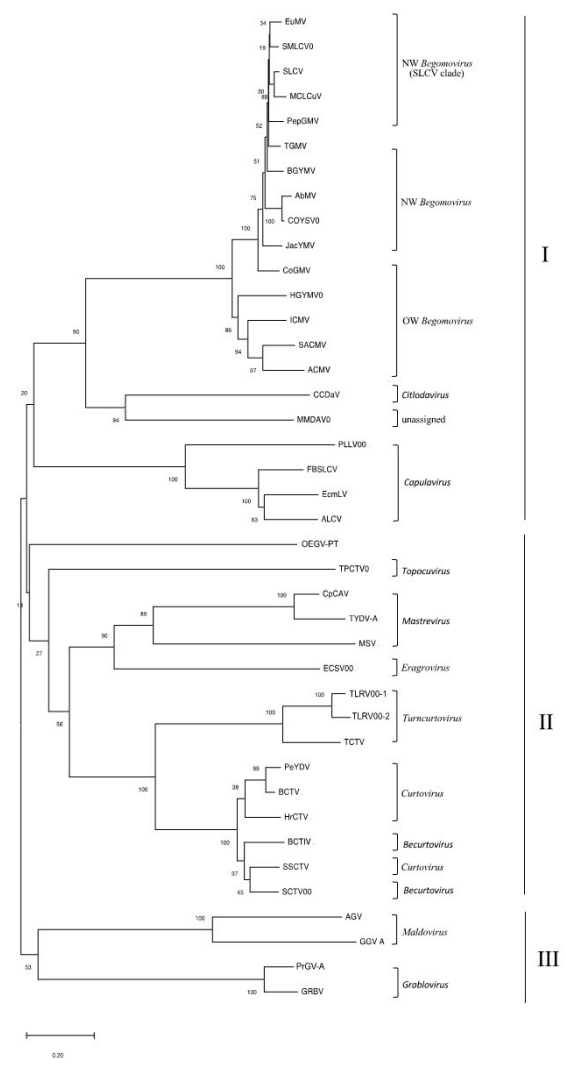

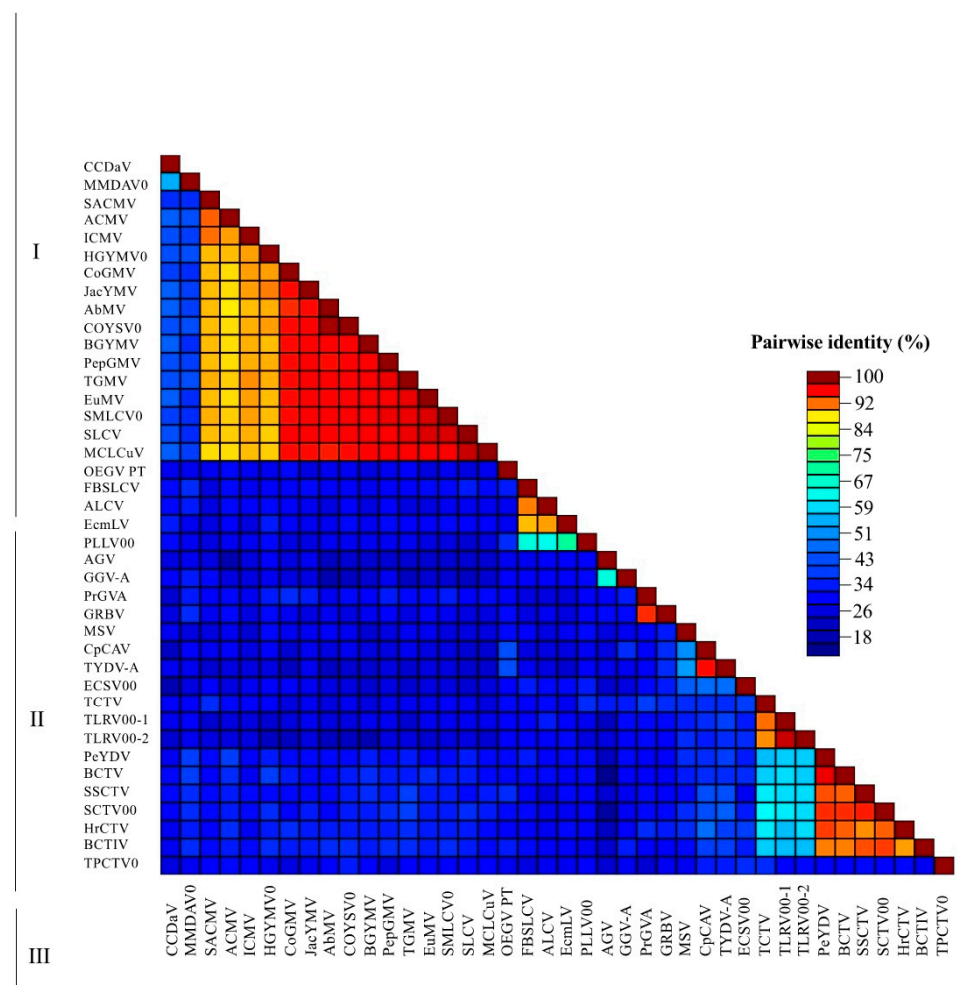

Figure 2. Phylogenetic trees constructed by the neighbor-joining (NJ) analysis from the alignment of the (A) OEGV PT full DNA-A (nt), (B) AC1/Rep (aa) and (C) AV1/CP (aa) from this study plus 39 sequences, with most representative geminiviruses including some isolates that had not yet been classified into genera, retrieved from the GenBank database. Virus genera, species and abbreviations, and GenBank accession numbers used in the NJ analysis are NW Begomovirus (SLCV clade); EuMV, SMLCV0, SLCV, PepGMV, MCLCuV, NW Begomovirus; AbMV, COYSV0, TGMV, BGYMV, JacYMV, OW Begomovirus; CoGMV, HGYMV0, SACMV, ACMV, ICMV, Mastrevirus; MSV, CpCAV, TYDV-A, Topocuvirus; TPCTV0, Turncurtovirus; TCTV, TLRV00-1, TLRV00-2, Curtovirus; PeYDV, BCTV, HrCTV, SSCTV, Eragrovirus; ECSV00, Capulavirus; FBSLCV, EcmLV, ALCV, PLLV00, Becurtovirus; BCTIV, SCTV00, Grablovirus; PrGV-A, GRBV, Citlodavirus; CCDaV, Maldovirus; AGV, GGV-A, and unassigned MMDAV0. Multiple sequence alignments were generated using MEGA 7 and the neighbor joining (BioNJ algorithms), based on calculations from pairwise nucleotide (nt) and amino acid (aa) sequences distances for full genome (nt) or proteins (aa) analysis. Numbers above the lines indicate bootstrap scores out of 1000 replicates. Roman numbers indicate the groups clustered in each phylogenetic tree.

The translation product of TrAP (AC2) (459 nt; 152 aa; $17.7 \mathrm{kDa}$ ) is related to the TrAP of the Begomovirus. Pairwise identities showed that the highest OEGV-PT TrAP identities $(>35 \%)$ were found with the NW Begomovirus, followed by OW Begomovirus and Maldovirus $(>29 \%)$. The lowest OEGV-PT TrAP identities $(<22 \%)$ were found with the Becurtovirus, Grablovirus and Mastrevirus. The translation product of replication enhancer protein (REn), ORF AC3, (441 nt; 146 aa; $18.3 \mathrm{kDa})$ is also related to the REn (AC3) of the Begomovirus. Pairwise identities showed that the highest OEGV-PT REn identities $(>30 \%)$ were found with the genera Begomovirus, Turncurtovirus and Topocuvirus. The lowest OEGV-PT Ren identities $(<22 \%)$ were found with the genera Grablovirus and Capulavirus.

Blastp analysis showed that the translation product of ORF AV1 (768 nt; 255 aa; $29.9 \mathrm{kDa}$ ) is most similar to the coat protein (CP) of the Mastrevirus TYDV-A (31\% identity; query coverage, $92 \%$; E value, $4 \times 10^{-14}$ ). Pairwise identities showed that the highest OEGV-PT CP identities were found with the genera Mastrevirus, Curtovirus, Turncurtovirus and Becurtovirus, which cluster together with OEGV-PT (cluster II), as revealed by the phylogenetic analysis of the $\mathrm{CP}$ of geminiviruses (Figure 2C). Two other clusters are composed by genera that present lower CP identities to OEGV-PT; one cluster contains 
Begomovirus, Capulavirus and Citlodavirus and the unassigned MMDaV0 (cluster I) and the other cluster contains Grablovirus and Maldovirus (cluster III).

Multiple alignment of the OEGV-PT Rep protein sequences showed that OEGV-PT has sequence motifs typical of geminivirus (Figure S2). In addition, pairwise analysis of OEGV-PT Rep showed higher similarities to NW Begomovirus and SLCV clade (Table S3). Interestingly, the alignment of Rep aa sequences showed, at the motif III, some aa homologies with the unique signatures of SLCV clade (Figure S2).

The OEGV-PT CP aa sequence displays low conserved amino acids between the geminivirus compared to Rep, however, it was interesting to verify several conserved amino acids regions (CR). Motif PWRsMaGT, conserved in the NW Begomovirus [44] is not present in the OEGV-PT. In addition, we identified several conserved regions (CR) within the geminivirus CP (CR I to CR VI) (Figure 3). These regions show many similarities with Mastrevirus corroborating our phylogenetic analysis and pairwise comparisons. Among these, CR I is conserved between OEGV-PT and the Mastrevirus (MSV) among other genera; CR III or putative motif candidates $\mathrm{R}(\mathrm{Rxx})$ presents the amino acid $\mathrm{R}$, at position 132, which is conserved among geminivirus and the sequence RHT is conserved between OEGVPT, Mastrevirus and Maldovirus. OEGV-PT also seems to be more similar to Mastrevirus and other genera in the $\mathrm{CR} V$ region, where it is clearly distinct from Begomovirus, that do not present this CP region. In addition, the CR VI region seems to be conserved among most geminiviruses used in this work, which may also indicate a putative motif candidates (ALY).

The BV1/MP of OEGV-PT DNA-B, showed the absence of the putative tyrosine phosphorylation site $[\mathrm{RK}]-\mathrm{x}(2,3)-[\mathrm{DE}]-\mathrm{x}(2,3)-\mathrm{Y}$, a site typically present in the NW Begomovirus and absent in OW Begomovirus. However, the comparison of the putative tyrosine phosphorylation site in the NW Begomovirus MP with the homologous region in OW Begomovirus MP and OEGV-PT MP showed that only one aa substitution (corresponding to a single nt substitution) would be needed to change the functionality of this site to the tyrosine phosphorylation site found in the NW Begomovirus MP (Figure 4).

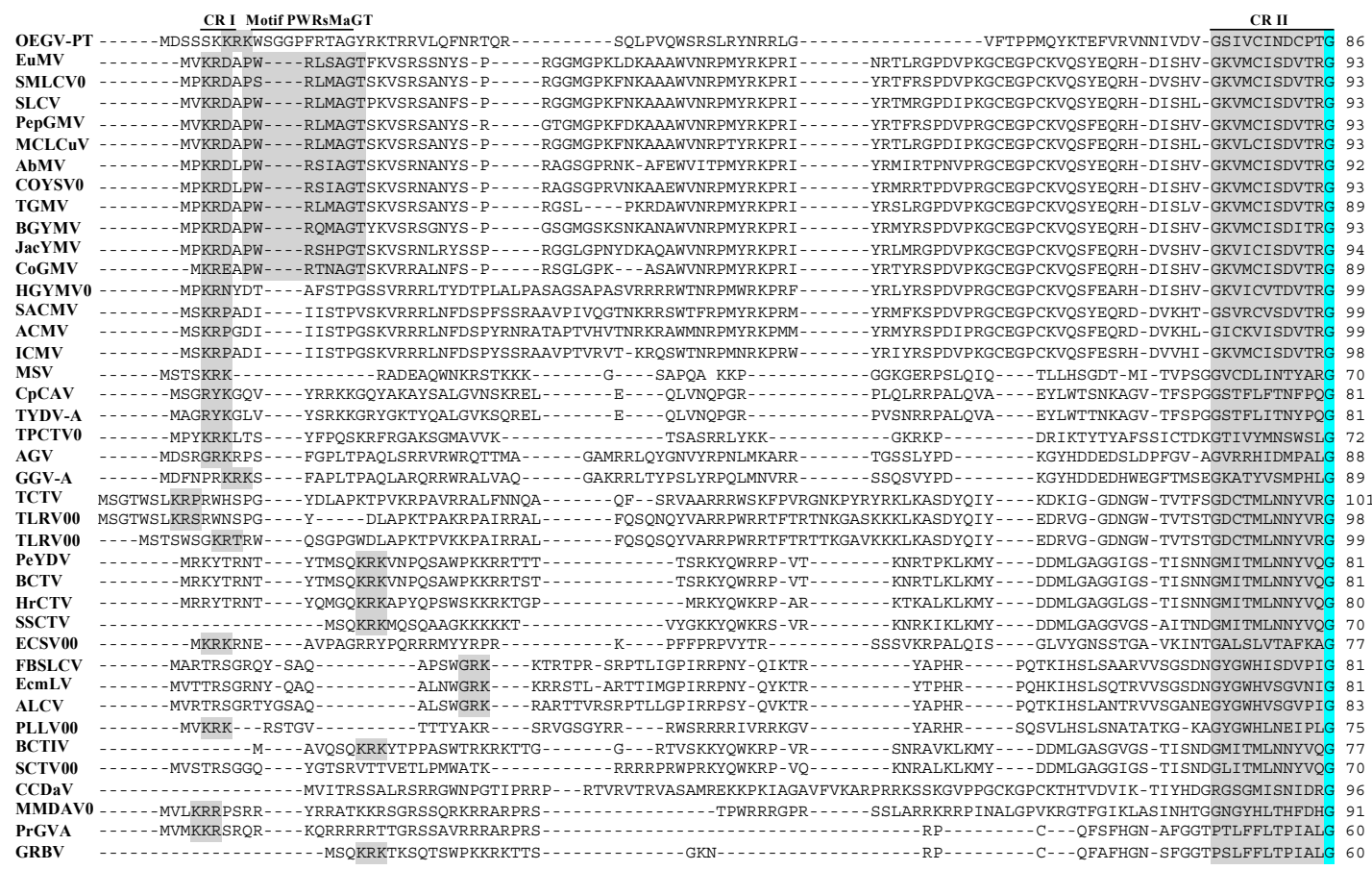

Figure 3. Cont. 


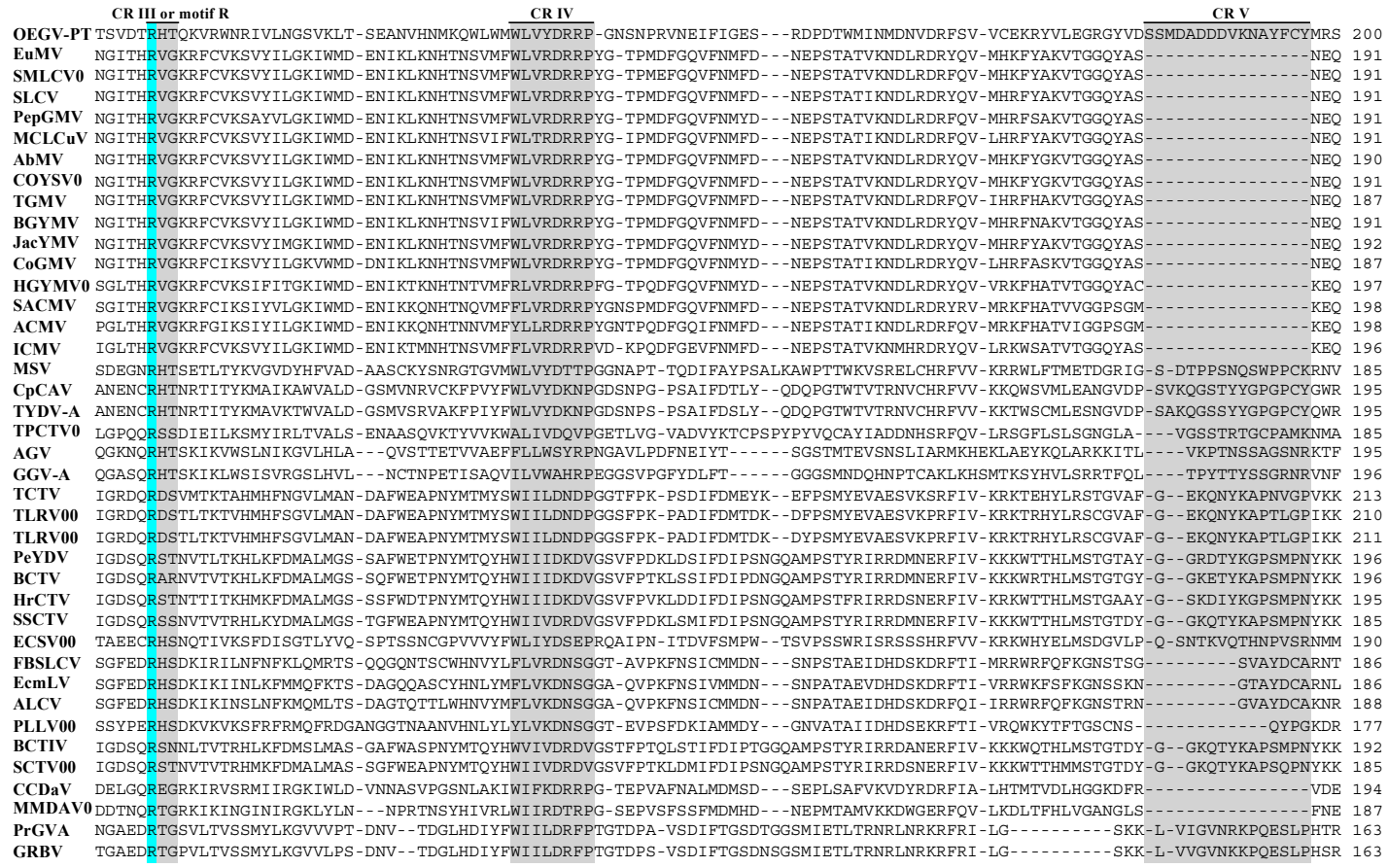
CR VI or motif ALY

\begin{tabular}{|c|c|c|}
\hline & & \\
\hline & TLKIRIYE & \\
\hline & & \\
\hline & J- & \\
\hline & RFWKVNNHV-VYNH - QEAGKYDNHTENA & \\
\hline IV & VQRFWKVNNHV - VYNH - QEAGKYENHTENALLLYMACTHASN - & \\
\hline & v- & \\
\hline GMV & VRRFWKVNNNV - VYNH - QEAGKYENHTENALLLYMACTHASN- & \\
\hline GYI & VRRFWKVNNHV - VYNH - QEAGKYENHAENALLLYMACTHASN & \\
\hline & & \\
\hline GMV & SLVRRFWKVNNHV-VYNH - QEAAKYDNHTENALLLYMACTHASN - & \\
\hline & & \\
\hline $\mathrm{CN}$ & ¿VRRFFRINNHV - VYNH - QEAAKYENHTENALLLYMACTHASN- & \\
\hline VI & $-A V$ & \\
\hline IV & VRRFFRVNNYV-VYNQ-QEAGKYENHTENALMLYMACTHASN- & \\
\hline & 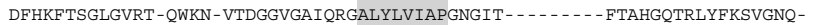 & \\
\hline & QMNKFFK & \\
\hline TYD & HVTKFFKRLGVST - EWKN - SSTGDVADIKEGALYLVCAPGGGAT - & \\
\hline & & \\
\hline $\mathrm{GV}$ & JQLKFRGRNAKYLTFQENATLGNWTDL & \\
\hline GV-A & FISSDA & \\
\hline $\mathbf{T}$ & & \\
\hline TLR & ISMVFR & \\
\hline & & \\
\hline PeYI & - & \\
\hline 3CT & CNMYATLF & \\
\hline & - & \\
\hline SSCT & TI & \\
\hline & KITIE & \\
\hline FBS & ICTIKY---VSIV-- & \\
\hline & & \\
\hline & & \\
\hline & ---ESI & \\
\hline & & \\
\hline & $1 \mathrm{~A}$ & \\
\hline & $T F$ & \\
\hline & & \\
\hline & & \\
\hline & & \\
\hline
\end{tabular}

Figure 3. Multiple alignment of OEGV-PT CP protein sequences with most representative geminiviruses including some isolates that had not yet been classified into genera, retrieved from the GenBank database. Gray boxes are highlighting several conserved regions (CR) or motifs, and blue indicate $100 \%$ homology between the geminivirus. Conserved regions (CR) or motifs; CR I, motif PWRsMaGT (conserved on NW Begomovirus), CR II, CR III or putative motif candidates $\mathrm{R}, \mathrm{CR}$ IV, CR V (amino acids enriched region in OEGV-PT) and CR VI or putative motif candidates ALY. Virus species and genera are NW Begomovirus (SLCV clade); EuMV, SMLCV0, SLCV, PepGMV, MCLCuV, NW Begomovirus; AbMV, COYSV0, TGMV, BGYMV, JacYMV, OW Begomovirus; CoGMV, HGYMV0, SACMV, ACMV, ICMV, Mastrevirus; MSV, CPCAV, TYDV-A, Topocuvirus; TPCTV0, Turncurtovirus; TCTV, TLRV00-1, TLRV00-2, Curtovirus; PeYDV, BCTV, HrCTV, SSCTV, Eragrovirus; ECSV00, Capulavirus; FBSLCV, EcmLV, ALCV, PLLV00, Becurtovirus; BCTIV, SCTV00, Grablovirus; PrGV-A, GRBV, Citlodavirus; CCDaV, Maldovirus; AGV, GGV-A, and unassigned genera; MMDaV. 


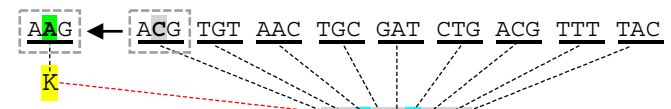

OEGV-PT VIEYRHQCPINSEGSVRIQVHDSRMMGTASKQAEFVMPVTCNCDLTFYGCWSSASSDEM $120 \ldots 303$

EuMV - - -YRRRPGSPNKAHDDSKMTNQRIHED---QFGPEFVLAHNMALSSYISFPSLTRTEPN $88 \quad \ldots 256$

SMLCVO VIEYRQQVPINASGTVIVEIHDKRMTDNESLQASWTFPIRCNIDLHYFSSSFFSLK-DPI $115 \quad \ldots 293$

SLCV VIEYRQQVPINASGTVIVEIHDKRMTDNESLQASWTFPIRCNIDLHYFSSSFFSLK-DPI $115 \quad \ldots 293$

PepGMV VIEYRQQVPINASGSVIVEIHDQRMTDNESLQASWTFPIRCNIDLHYFSSSFFSLK-DPI $115 \quad \ldots 289$

AbMV VIEYRQQVPINATGSVIVEIHDKRMTESESLQASWTFPIRCNIDLHYFSASFFSLK-DPI $115 \quad \ldots 293$

COYSVO VIEYRQQVPINAAGTVIVEIHDKRMTDNESLQASWTXPIRCNIDLHYFSASFFSLK-DPI $115 \quad \ldots 293$

TGMV VIEFRQQVPINATGSVVVEIHDKRMTDNESLQASWTFPVRCNIDLHYFSSSFFSLK-DPI $115 \quad \ldots \quad 293$

BGYMV VIEYRQQVPINATGSVVVEIHDKRMTDNESLQASWTFPIRCNIDLHYFSSSFFSLK-DPI $115 \quad \ldots 293$

JacYMV VIEYRQQVPINAAGTVIVEIHDMRMQDNESLQASWTFPIRCNIDLHFFSSSFFSLK-DQV $115 \quad \ldots 293$

CoGMV VIEYRQQVPINASGSVIVEIHDTRMNDNESLQTTYTFPIRCNIDLHYFSASFFSLK-DPI $115 \quad \ldots 292$

SACMV IIEYRNQVPFNATGSVIVEIRDNRVSLDDAAQAAFTFPIACNVDLHYFSSTYFSIS-EPS $113 \quad \ldots \quad 307$

ICMV VLEYRNQVPINATGHVIIEIHDQRLHDGDSKQAEFTIPVQCNCNLHYYSSSFFSMK-DIN $111 \ldots 286$

Figure 4. Alignment of OEGV-PT DNA-B MP aa sequences with begomoviruses showing (in gray) the putative tyrosine phosphorylation site [RK]-x(2,3)-[DE]-x(2,3)-Y in the NW Begomovirus and the homologous OW and OEGV-PT region. On top, codons of OEGV-PT sequence are shown. In green is shown how a single nt substitution (C by A) in the first codon of the site would be enough to change the functionality of tyrosine phosphorylation (T by K) in OEGV-PT. Blue shaded aa represent conserved aa among begomoviruses.

\subsection{Recombination Analysis}

The RDP analysis identified two recombination events for OEGV-PT (Figure 5), both well supported by at least five methods in the RDP4 package. One event (event 1) showed a recombination with the beginning breakpoint at nucleotide 141 (IR) and ending breakpoint at nucleotide 1506 (Rep and TrAP), involving a segment of $1365 \mathrm{nt}$ long, encompassing the complete putative CP last, the complete C3, the last $433 \mathrm{nt}$ of the TrAP and the last $63 \mathrm{nt}$ of the putative OEGV Rep. This segment was putatively derived from an unknown minor parent and from the NW Begomovirus BGYMV (major parent). A second event (event 2) showed a recombination with the beginning breakpoint at nucleotide 2258 (Rep) and ending breakpoint at nucleotide 2720 (IR), involving a segment of $462 \mathrm{nt}$ long, encompassing the first $259 \mathrm{nt}$ of the putative OEGV Rep. This segment was putatively derived from ICMV (minor parent) and ACMV (major parent), both OW Begomovirus. No clear evidence for recombination was found in DNA-B.

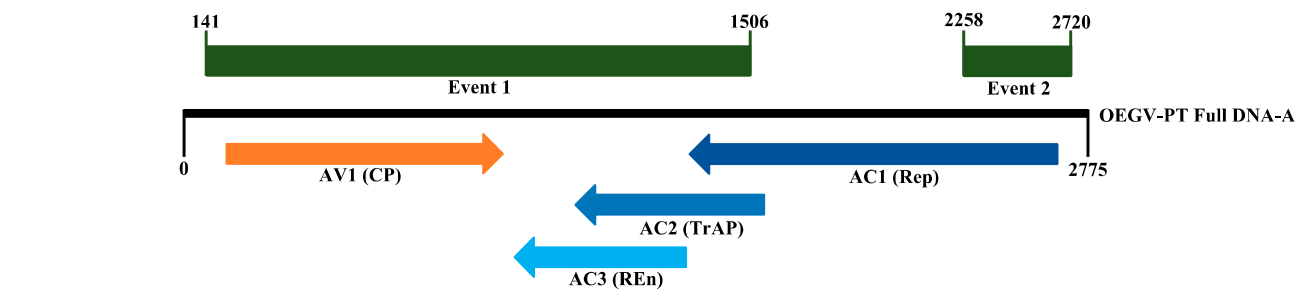

\begin{tabular}{ccccccccccc}
\hline \multirow{2}{*}{ Event } & \multirow{2}{*}{$\begin{array}{c}\text { Minor } \\
\text { parent }\end{array}$} & \multirow{2}{*}{$\begin{array}{c}\text { Major } \\
\text { parent }\end{array}$} & Beginning & Ending & \multicolumn{5}{c}{ Method (p - Value) } \\
\cline { 6 - 10 } & breakpoint & breakpoint & RDP & GENECONV & MaxChi & Chimaera & SiScan & 3 Seq \\
\hline \multirow{2}{*}{1} & Unknown & BGYMV & 141 & 1506 & $4.244 \times 10^{\wedge}-11$ & $3.454 \times 10^{\wedge}-3$ & $9.95 \times 10^{\wedge}-19$ & $2.755 \times 10^{\wedge}-6$ & $8.954 \times 10^{\wedge}-49$ & $3.034 \times 10^{\wedge}-1$ \\
2 & ICMV & ACMV & 2258 & 2720 & $1.259 \times 10^{\wedge}-2$ & - & $2.241 \times 10^{\wedge}-4$ & $1.068 \times 10^{\wedge}-2$ & $2.935 \times 10^{\wedge}-08$ & $2.317 \times 10^{\wedge}-2$ \\
\hline \hline
\end{tabular}

Figure 5. Schematic representation of the recombination events detected by RDP4.101 in OEGV-PT genome and corresponding p-values. A simplified linearized map was used to represent OEGV-PT full DNA-A. The floating boxes above the genome show the position of the two recombination events in OEGV-PT DNA-A. The floating arrows below the genome correspond to the position of each of the putative OEGV genes.

\subsection{Specificity-Determining Positions (SDPs) in CP Amino Acid Sequences}

The automatic subgrouping allowed us to divide geminiviruses into eight groups that share the same type of insect vector (Table 2). SDP analysis did not cluster OEGV-PT together with any of the viral groups with known vectors. 
Table 2. Specificity-determining positions (SDPs) alignment for the $\mathrm{CP}$ amino acid sequences of the geminivirirus. $\mathrm{CP}$ multiple sequence alignment by clustalX code. The sequences were automatically divided into eight groups by SCI-PHY and SDPs calculated by the SPEER server. The columns indicate the groups, genera, virus species (acronym), known insect vectors, the aa predicted to determine differences in virus vector specificity and respective positions in the $C P$ multiple alignments. The gray boxes indicate the homologies in the specific aa.

\begin{tabular}{|c|c|c|c|c|c|c|c|c|c|c|c|c|}
\hline \multirow{2}{*}{ Groups } & \multirow{2}{*}{ Genera } & \multirow{2}{*}{ Species } & \multirow{2}{*}{ Vectors } & \multicolumn{9}{|c|}{ Amino Acids and Positions } \\
\hline & & & & 102 & 120 & 137 & 144 & 244 & 247 & 253 & 256 & 268 \\
\hline \multirow{2}{*}{1} & Citlodavirus & $\mathrm{CCDaV}$ & \multirow{5}{*}{ unknown } & $\mathrm{M}$ & I & $\mathrm{N}$ & $\mathrm{N}$ & $\mathrm{F}$ & $\mathrm{H}$ & $\mathrm{V}$ & $\mathrm{T}$ & $\mathrm{S}$ \\
\hline & unassigned & MMDAV0 & & $\mathrm{H}$ & I & $\mathrm{N}$ & $\mathrm{H}$ & Y & $\mathrm{H}$ & $\mathrm{L}$ & $\mathrm{V}$ & S \\
\hline \multirow[b]{2}{*}{2} & \multirow{2}{*}{ Maldovirus } & AGV & & $\mathrm{H}$ & I & $\mathrm{Q}$ & V & $\mathrm{Q}$ & $\mathrm{N}$ & $W$ & $\mathrm{~L}$ & $\mathrm{~V}$ \\
\hline & & GGV-A & & $\mathrm{Y}$ & I & $\mathrm{N}$ & I & $\mathrm{G}$ & $\mathrm{D}$ & $\mathrm{Y}$ & I & I \\
\hline \multirow[b]{2}{*}{3} & \multirow{2}{*}{ Grablovirus } & PrGV-A & & $\mathrm{F}$ & $\mathrm{L}$ & V & $\mathrm{H}$ & $\mathrm{K}$ & $\mathrm{D}$ & $\mathrm{R}$ & V & $\mathrm{A}$ \\
\hline & & GRBV & S. festinus & $\mathrm{F}$ & $\mathrm{L}$ & V & $\mathrm{H}$ & $\mathrm{K}$ & $\mathrm{D}$ & $\mathrm{R}$ & V & $\mathrm{A}$ \\
\hline \multirow{4}{*}{4} & Eragrovirus & ECSV00 & \multirow{4}{*}{ leafhopper } & $\mathrm{L}$ & $\mathrm{T}$ & $\mathrm{T}$ & V & $\mathrm{W}$ & $S$ & I & I & $\mathrm{R}$ \\
\hline & & MSV & & $\mathrm{L}$ & $\mathrm{T}$ & S & G & W & $\mathrm{N}$ & V & I & G \\
\hline & Mastrevirus & CpCAV & & $\mathrm{L}$ & $\mathrm{T}$ & $\mathrm{M}$ & $\mathrm{F}$ & W & $\mathrm{N}$ & V & I & A \\
\hline & & TYDV-A & & $\mathrm{L}$ & $\mathrm{T}$ & M & F & $\mathrm{W}$ & $\mathrm{N}$ & V & I & G \\
\hline \multirow{4}{*}{5} & \multirow{4}{*}{ Capulavirus } & EcmLV & A. tirucallis & $\mathrm{H}$ & I & A & $\mathrm{Y}$ & $\mathrm{F}$ & $S$ & $\mathrm{Y}$ & $\mathrm{T}$ & Q \\
\hline & & ALCV & A. craccivora & $\mathrm{H}$ & I & A & $\mathrm{W}$ & $\mathrm{F}$ & S & $\mathrm{Y}$ & $\mathrm{T}$ & $\widehat{\mathrm{Q}}$ \\
\hline & & FBSLCV & \multirow{2}{*}{ unknown } & $\mathrm{H}$ & I & $\mathrm{Q}$ & W & $\mathrm{F}$ & S & $\mathrm{Y}$ & $\mathrm{T}$ & $\mathrm{Q}$ \\
\hline & & PLLV00 & & $\mathrm{H}$ & V & $\tilde{G}$ & V & $\mathrm{F}$ & $S$ & $\mathrm{Y}$ & $\mathrm{T}$ & $\widehat{Q}$ \\
\hline \multirow{3}{*}{6} & \multirow{3}{*}{ Turncurtovirus } & TCTV & \multirow{3}{*}{ C. haematoceps } & $\mathrm{M}$ & $\mathrm{T}$ & $\mathrm{F}$ & $\mathrm{M}$ & W & $\mathrm{D}$ & $\mathrm{Y}$ & $\mathrm{L}$ & $\mathrm{D}$ \\
\hline & & TLRV00-1 & & M & $\mathrm{T}$ & $\mathrm{F}$ & $\mathrm{M}$ & $\mathrm{W}$ & $\mathrm{D}$ & $\mathrm{Y}$ & $\mathrm{L}$ & $\mathrm{D}$ \\
\hline & & TLRV00-2 & & M & $\mathrm{T}$ & $\mathrm{F}$ & $\mathrm{M}$ & W & $\mathrm{D}$ & $\mathrm{Y}$ & $\mathrm{L}$ & $\mathrm{D}$ \\
\hline \multirow{6}{*}{7} & \multirow{4}{*}{ Curtovirus } & PeYDV & \multirow{2}{*}{ C. tenellus } & M & $\mathrm{T}$ & $\mathrm{F}$ & $\mathrm{M}$ & W & $\mathrm{D}$ & $\mathrm{Y}$ & V & $\mathrm{D}$ \\
\hline & & BCTV & & M & $\mathrm{T}$ & $\mathrm{F}$ & M & $\mathrm{W}$ & $\mathrm{D}$ & $\mathrm{Y}$ & V & $\mathrm{D}$ \\
\hline & & HrCTV & & M & $\mathrm{T}$ & $\mathrm{F}$ & $\mathrm{M}$ & W & $\mathrm{D}$ & $\mathrm{Y}$ & V & $\mathrm{D}$ \\
\hline & & SSCTV & unknown & M & $\mathrm{T}$ & $\mathrm{F}$ & $\mathrm{M}$ & $\mathrm{W}$ & $\mathrm{D}$ & $\mathrm{Y}$ & $\mathrm{V}$ & $\mathrm{D}$ \\
\hline & & SCTV00 & & M & $\mathrm{T}$ & $\mathrm{F}$ & $\mathrm{M}$ & W & $\mathrm{D}$ & $\mathrm{Y}$ & $\mathrm{V}$ & $\mathrm{D}$ \\
\hline & Becurtovirus & BCTIV & C. haematoceps & M & $\mathrm{T}$ & $\mathrm{F}$ & M & $\mathrm{W}$ & $\mathrm{D}$ & Y & $\mathrm{V}$ & $\mathrm{D}$ \\
\hline & & EuMV & & $\mathrm{C}$ & $\mathrm{F}$ & I & $\mathrm{N}$ & $\mathrm{Y}$ & $\mathrm{H}$ & $\mathrm{Y}$ & $\mathrm{H}$ & $\mathrm{T}$ \\
\hline & & SMLCV0 & & $\mathrm{C}$ & $\mathrm{F}$ & I & $\mathrm{N}$ & $\mathrm{Y}$ & $\mathrm{H}$ & $\mathrm{Y}$ & $\mathrm{H}$ & $\mathrm{T}$ \\
\hline & & SLCV & & $\mathrm{C}$ & $\mathrm{F}$ & I & $\mathrm{N}$ & $\mathrm{Y}$ & $\mathrm{H}$ & $\mathrm{Y}$ & $\mathrm{H}$ & $\mathrm{T}$ \\
\hline & & PepGMV & & $\mathrm{C}$ & $\mathrm{F}$ & I & $\mathrm{N}$ & $\mathrm{Y}$ & $\mathrm{H}$ & $\mathrm{Y}$ & $\mathrm{H}$ & $\mathrm{T}$ \\
\hline & & MCLCuV & & $\mathrm{C}$ & $\mathrm{F}$ & I & $\mathrm{N}$ & $\mathrm{Y}$ & $\mathrm{H}$ & $\mathrm{Y}$ & $\mathrm{H}$ & $\mathrm{T}$ \\
\hline & & AbMV & & $\mathrm{C}$ & $\mathrm{F}$ & I & $\mathrm{N}$ & $\mathrm{Y}$ & $\mathrm{H}$ & $\mathrm{Y}$ & $\mathrm{H}$ & $\mathrm{T}$ \\
\hline & & COYSV0 & & $\mathrm{C}$ & $\mathrm{F}$ & I & $\mathrm{N}$ & $\mathrm{Y}$ & $\mathrm{H}$ & $\mathrm{Y}$ & $\mathrm{H}$ & $\mathrm{T}$ \\
\hline 8 & Begomovirus & TGMV & B. tabaci & $\mathrm{C}$ & $\mathrm{F}$ & I & $\mathrm{N}$ & $\mathrm{Y}$ & $\mathrm{H}$ & $\mathrm{Y}$ & $\mathrm{H}$ & $\mathrm{T}$ \\
\hline & & BGYMV & & $\mathrm{C}$ & F & I & $\mathrm{N}$ & $\mathrm{Y}$ & $\mathrm{H}$ & $\mathrm{Y}$ & $\mathrm{H}$ & $\mathrm{T}$ \\
\hline & & JacYMV & & $\mathrm{C}$ & $\mathrm{F}$ & I & $\mathrm{N}$ & $\mathrm{Y}$ & $\mathrm{H}$ & $\mathrm{Y}$ & $\mathrm{H}$ & $\mathrm{T}$ \\
\hline & & CoGMV & & $\mathrm{C}$ & $\mathrm{F}$ & I & $\mathrm{N}$ & $\mathrm{Y}$ & $\mathrm{H}$ & $\mathrm{Y}$ & $\mathrm{H}$ & $\mathrm{T}$ \\
\hline & & HGYMV0 & & $\mathrm{C}$ & $\mathrm{F}$ & I & $\mathrm{N}$ & $\mathrm{Y}$ & $\mathrm{H}$ & $\mathrm{Y}$ & $\mathrm{H}$ & $\mathrm{T}$ \\
\hline & & SACMV & & $\mathrm{C}$ & F & I & $\mathrm{N}$ & $\mathrm{Y}$ & $\mathrm{H}$ & $\mathrm{Y}$ & $\mathrm{H}$ & $\mathrm{T}$ \\
\hline & & ACMV & & V & F & I & $\mathrm{N}$ & Y & $\mathrm{H}$ & $\mathrm{Y}$ & $\mathrm{H}$ & $\mathrm{T}$ \\
\hline & & ICMV & & $\mathrm{C}$ & $\mathrm{F}$ & I & $\mathrm{N}$ & $\mathrm{Y}$ & $\mathrm{Q}$ & $\mathrm{Y}$ & $\mathrm{H}$ & $\mathrm{T}$ \\
\hline- & unassigned & OEGV-PT & & $\mathrm{C}$ & V & A & $\mathrm{Q}$ & $\mathrm{F}$ & $\mathrm{D}$ & V & $\mathrm{M}$ & $\mathrm{F}$ \\
\hline - & Topocuvirus & TPCTV0 & unknown & Y & $\mathrm{E}$ & A & $\mathrm{Y}$ & Y & $\mathrm{D}$ & I & I & $\mathrm{D}$ \\
\hline
\end{tabular}

\section{Discussion}

The advent of HTS has greatly increased the rate of plant virus discovery, from 900 species in 2005 to 9110 species in 2021. However not all newly discovered plant viruses induce disease symptoms and their biological relevance presents a major challenge to plant pathologists and policy makers. Whilst studies on plant virus identification by HTS are dominated by herbaceous crops [45,46], those analyzing woody crops are less prevalent, probably due to the difficulty of obtaining high quality RNA. However, grapevines and citrus trees are an exception, most likely due to their economic importance [47-49].

In this work we performed HTS in olive and we identified OEGV in Portugal (OEGVPT). The initial sequence results enabled us to sequence the full genome of the bipartite 
OEGV-PT. The OEGV-PT genome is identical, 100\% in DNA-A and 99\% in DNA-B, to the recently described OEGV [8], but further genomic and phylogenetic analyses performed in this work show that OEGV presents genomic characteristics from both OW and NW Begomovirus, different to presented previously [8]. These results were possible through a higher representativeness of geminivirus isolates in phylogenetic analysis, especially with the inclusion of NW Begomovirus from SLCV clade. Members of the NW Begomovirus SLCV lineage display features that distinguishes them from other NW begomoviruses [50], and in this study it was possible to identify several aa homologies in motif III in the N-terminal of OEGV-PT Rep which presents unique signatures of SLCV clade, and which may have contributed to the increased similarities with this lineage.

The length of both OEGV-PT DNAs is typical of the OW Begomovirus [51] but OEGV-PT genome organization is similar to NW Begomovirus, but no AC4/C4, typical of both NW and OW Begomovirus, was found. C4 is required for monopartite Begomovirus infection and for a few bipartite begomoviruses [52,53]. C4/AC4 is related to the induction of characteristic viral symptoms $[54,55]$ and has been suggested to interact with CP and/or MP to transport the replicated genome from the nucleus to the cytoplasm and from cell-to-cell [56]. No begomoviruses lacking C4/ AC4 have been described until now, however, other genera within the Geminiviridae: Becurtovirus, Capulavirus, Grablovirus, Eragrovirus, Mastrevirus and other species also lack C4, showing that in these viruses $C 4$ is not essential for viral infection and function may be compensated by other viral proteins.

DNA-B components are only present in members of genus Begomovirus (mostly from NW and less from OW). OEGV-PT DNA-B comprises two ORFs: BC1/unknown, was found in the complementary sense and BV1/MP in the virion sense, in contrast to all other known bipartite begomoviruses, where MP is in complementary sense. In OEGV-PT MP, a single nt substitution would be needed to change this site into a functional tyrosine phosphorylation site, placing OEGV-PT DNA-B closer to NW Begomovirus and suggesting that OEGV-PT MP is under purifying selection. Tyrosine phosphorylation has shown to be involved in plant virus localization and cell to cell movement [57] and, in OW Begomovirus, the lack of the tyrosine phosphorylation function, may be compensated by AV2 [58,59]. It is, however, interesting to observe that OEGV-PT lacks AV2, and viruses that lack AV2, such as NW Begomovirus, must rely on DNA-B proteins for infectivity [20]. Our phylogenetic analyses showed important differences in OEGV-PT movement proteins in relation to all other geminiviruses. OEGV-PT proteins (including BC1) must have acquired novel roles during evolution, that allow host infection even in the absence of the AV2, AC4 and NSP. Further experiments are required to uncover the current functions of OEGV-PT proteins and understand the mechanisms of infection and movement within the host.

An additional clear distinct feature of OEGV-PT DNA-A and DNA-B is the length of its common region (CR), $403 \mathrm{nt}$, in opposition to the $348 \mathrm{nt}$ recently referred by Chiumenti [8] for OEGV, which is, to our knowledge, the longest CR observed between DNA-A and its cognate DNA-B. In addition, it was interesting to verify that the OEGV-PT DNA-A and DNA-B CR contains the TATA box and four replication-associated iterons with a unique arrangement compared to the other known geminiviruses, and these sites are a major determinant of virus-specific replication [60,61], preventing Rep from replicating noncognate DNA-A and DNA-B components showing a very strong specificity between DNA-A and DNA-B and that reassortment in OEGV-PT is very unlikely to occur.

Our analysis of the OEGV-PT proteins showed that whilst other virus proteins were most closely related to the Begomovirus, OEGV-PT CP was more closely related to Mastrevirus and Curtovirus (Figure 3C). The low sequence identity of the OEGV-PT CP with other known genera, suggest that this protein presents functions that may be a mixture from different geminiviruses. For example, it is interesting to note that in bipartite Begomovirus, nucleocytoplasmic transport is provided by NSP and in monopartite viruses this function is fulfilled by the CP [62,63]; this may be the case in OEGV-PT, as it lacks a typical NSP. In addition to that and despite the high diversity between the OEGV-PT CP and the CP from other members of the family Geminiviridae, it is possible to suggest, based on the amino 
acid CP alignment, two new putative motif candidates (CR III or motif R and CR VI or motif ALY) among the geminiviruses, although functional studies with OEGV must be carried out to confirm the existence of new motifs in the family Geminiviridae or among some genera.

Among several roles of the viral CP, such as viral movement and infectivity [64-67], the $\mathrm{CP}$ is known to be involved in vector transmission and specificity [68-70]. Interestingly, Mastrevirus and Curtovirus are transmitted by leafhoppers, in opposition to the whitefly vectors of begomoviruses. It has been shown that $\mathrm{CP}$ of geminiviruses that share an insect vector cluster together in phylogenetic analyses. Here, we showed that OEGV-PT CP clustered together with Mastrevirus, Turncurtovirus, Curtovirus and Becurtovirus, which are transmitted by leafhoppers, suggesting that OEGV-PT CP similarities may reflect shared vectors. However, further clustering analysis suggested that the OEGV-PT vector, if any, may be different from those described for known geminiviruses. Further experiments are needed to gain information on the OEGV-PT vector. The low similarity of the OEGV-PT $\mathrm{CP}$ with begomoviruses CPs, may be the result of an adaptation of an ancient Begomovirus which lost the capacity to be transmitted by the whitefly Bemisia tabaci, an insect that is not frequently found in olive, and adapted for a more successful dissemination in this new host.

There are an increasing number of studies that show that bipartite begomoviruses, typical of NW are found in the OW and monopartite begomoviruses, typical of OW are being found in the NW [21,71,72]. Our data support the conclusion that the evolution of bipartite begomoviruses occurred following the appearance of monopartite species which acquired a DNA-B component, probably derived from the original DNA-A. Although the OEGV-PT CP is more similar to those of Mastrevirus and Curtovirus, our search of possible recombination events in OEGV-PT DNA-A did not show any recombination with these genera, instead, two recombination events for OEGV-PT, both involving begomoviruses were detected, suggesting that OEGV-PT evolved from begomoviruses. Due to the fact that no other geminiviruses have been found in olive, we suggest that OEGV-PT evolution occurred in a different host and may have started with an ancient OW monopartite Begomovirus that lost V2 and C4, gaining functions on cell to cell movement by acquiring a DNA-B component. The invasion of new host cells may have facilitated its acquisition by a new polyphagous vector that mediated its introduction into olive. Intensive surveys that include sampling of wild relatives and weed species near the infected orchards would help to gain insight into the origins of OEGV-PT.

Our characterization of OEGV-PT, highlighting for the first time the similarities and differences to both OW and NW begomoviruses as well as Mastreviruses and Curtoviruses, clearly shows that this virus represents a new evolutionary direction in the Geminiviridae. HTS allows the identification of asymptomatic novel geminiviruses, as is the case of OEGV$\mathrm{PT}$, and it is possible that evolution is favoring less pathogenic variants. Alternatively, such viruses may have alternative hosts that function as reservoirs, from which they are transmitted to new hosts, where they cause emergent and sometimes devastating diseases.

As more geminiviruses are discovered, there is a clear need to better understand their evolutionary traits and host impact. Whilst OEGV-PT is currently asymptomatic in olive, studies concerning its cellular location, symptoms, transmission, are essential to elucidate host-virus interactions and prevent it becoming an emergent disease in an alternative economically important host.

Supplementary Materials: The following are available online at https:/ / www.mdpi.com/article/10 .3390 /v13102035/s1, Figure S1: Genome representation of the circular single stranded DNA-A and DNA-B of OEGV-PT. The relative position of four (DNA-A) and two (DNA-B) predicted ORFs. DNA$\mathrm{A}$ : $\mathrm{CR}$, common region sequence; $\mathrm{AV} 1$, coat protein $(\mathrm{CP})$; $\mathrm{AC1}$, replication-associated protein (Rep); $\mathrm{AC} 2$, transcriptional activator protein ( $\mathrm{Tr} A \mathrm{P})$; $\mathrm{AC} 3$, replication enhancer protein (REn); DNA-B: CR, common region sequence; BV1, movement protein (MP); BC1, unknown. Stem-loop of the DNA-A and DNA-B: nonanucleotide sequence "TAATATT $\downarrow$ AC" shown in red arc box (nucleotide position 2769 or 2757 to 2 ). The $\downarrow$ (black arrow) indicates position 1 in the viral genome corresponding to the 
predicted replication origin of the viral DNA. Arrows denote the virion-sense (V) and complementarysense $(C)$ geminiviral genes encoded by each component. Figure S2: Multiple alignment of the OEGVPT Rep protein sequences with most representative geminiviruses including some isolates that had not yet been classified into genera, retrieved from the GenBank database. Gray boxes are highlighting several conserved motifs and blue indicates $100 \%$ homology between geminivirus. Motifs; I, II, III, GRS, RBR, walker A, RxL, walker B and motifi C. Virus species and genera are NW Begomovirus (SLCV clade); EuMV, SMLCV0, SLCV, PepGMV, MCLCuV, NW Begomovirus; AbMV, COYSV0, TGMV, BGYMV, JacYMV, OW Begomovirus; CoGMV, HGYMV0, SACMV, ACMV, ICMV, Mastrevirus; MSV, CPCAV, TYDV-A, Topocuvirus; TPCTV0, Turncurtovirus; TCTV, TLRV00-1, TLRV00-2, Curtovirus; PeYDV, BCTV, HrCTV, SSCTV, Eragrovirus; ECSV00, Capulavirus; FBSLCV, EcmLV, ALCV, PLLV00, Becurtovirus; BCTIV, SCTV00, Grablovirus; PrGV-A, GRBV, Citlodavirus; CCDaV, Maldovirus; AGV, GGV-A, and unassigned MMDaV. Table S1: Specific pairs of primers designed based on the two different contigs (2727 and 1286 bp) to recover full-length DNAs (DNA-A and DNA-B), Table S2: Genera, species, acronyms, and GenBank accession numbers of the DNA-A (full DNA, Rep, CP) and DNA-B (full DNA, NSP and MP) of the geminiviruses used in this study, Table S3: Percentages of homology between OEGV-PT DNA-A (full DNA, Rep, TrAP, REn and CP) and DNA-B (DNA-B and $\mathrm{MP}$ ) and selected geminivirus (DNAs and predicted proteins).

Author Contributions: Conceptualization, P.M., S.J. and C.M.R.V.; resources, C.M.R.V., M.d.R.F., A.B.D. and P.M.; methodology, P.M., S.J., C.M.R.V., M.P., M.D.C. and A.B.D.; writing-original draft preparation, P.M., S.J. and C.M.R.V.; writing-review and editing, P.M., C.M.R.V., S.J., M.d.R.F., M.D.C. and M.P.; funding acquisition, C.M.R.V. and P.M. All authors have read and agreed to the published version of the manuscript.

Funding: This work was funded by the projects "Control of olive anthracnose through gene silencing and gene expression using a plant virus vector" with the references ALT20-03-0145-FEDER-028263 and PTDC/ASP-PLA/28263/2017 and "Development of a new virus-based vector to control TSWV in tomato plants" with the references ALT20-03-0145-FEDER-028266 and PTDC/ASP-PLA/28266/2017, both co-financed by the European Union through the European Regional Development Fund, under the ALENTEJO 2020 (Regional Operational Program of the Alentejo), ALGARVE 2020 (Regional Operational Program of the Algarve) and through the Foundation for Science and Technology, in its national component. M.P. was supported by Portuguese National Funds through FCT/MCTES, under the PhD scholarship SFRH/BD/145321/2019, co-financed by the European Social Fund through the Regional Operational Program of the Alentejo. S.J was additionally supported by the Scottish Government's Rural and Environment Science and Analytical Services division (RESAS).

Institutional Review Board Statement: Not applicable.

Informed Consent Statement: Not applicable.

Data Availability Statement: The datasets presented in this study can be found in online repositories. The names of the repositories and accession numbers of both DNA-A and DNA-B can be found below: https:/ / www.ncbi.nlm.nih.gov/genbank/, accessed on 2 September 2021, MZ355666, MZ355667, respectively.

Acknowledgments: We would like to thank Ian Adams and his colleagues at the Fera Science Ltd. for their excellent work on the RNA sequencing of olive samples.

Conflicts of Interest: The authors declare no conflict of interest.

\section{References}

1. Al Abdullah, A.; El Beaino, T.; Saponari, M.; Hallak, H.; Digiaro, M. Preliminary evaluation of the status of olive-infecting viruses in Syria. EPPO Bull. 2005, 35, 249-252. [CrossRef]

2. Fadel, C.; Digiaro, M.; Choueiri, E.; El Beaino, T.; Saponari, M.; Savino, V.; Martelli, G.P. On the presence and distribution of olive viruses in Lebanon. EPPO Bull. 2005, 35, 33-36. [CrossRef]

3. Faggioli, A.F.; Ferretti, L.; Albanese, G.; Sciarroni, R.; Pasquini, G.; Lumia, V.; Barba, M. Distribution of olive tree viruses in Italy as revealed by one-step RT-PCR. J. Plant Pathol. 2005, 87, 49-55.

4. Varanda, C.; Cardoso, J.M.S.; do Rosário Félix, M.; Oliveira, S.; Clara, M.I. Multiplex RT-PCR for detection and identification of three necroviruses that infect olive trees. Eur. J. Plant Pathol. 2010, 127, 161-164. [CrossRef]

5. Luigi, M.; Godena, S.; Dermić, E.; Barba, M.; Faggioli, F. Detection of viruses in olive trees in Croatian Istria. Phytopathol. Mediterr. 2011, 50, 150-153. [CrossRef] 
6. Félix, M.R.; Varanda, C.M.R.; Clara, M.I. Biology and molecular characterization of necroviruses affecting Olea europaea L.: A review. Eur. J. Plant Pathol. 2012, 133, 247-259. [CrossRef]

7. Zellama, M.S.; Varanda, C.M.R.; Materatski, P.; Nabi, N.; Hafsa, A.B.; Saamali, B.M.; Chaouachi, M.; Félix, M.R. An integrated approach for understanding the high infection rates of olive viruses in Tunisia. Eur. J. Plant Pathol. 2019, 153, $1043-1054$. [CrossRef]

8. Chiumenti, M.; Greco, C.; De Stradis, A.; Loconsole, G.; Cavalieri, V.; Altamura, G.; Zicca, S.; Saldarelli, P.; Saponari, M. Olea Europaea Geminivirus: A Novel Bipartite Geminivirid Infecting Olive Trees. Viruses 2021, 13, 481. [CrossRef] [PubMed]

9. Xylogianni, E.; Margaria, P.; Knierim, D.; Sareli, K.; Winter, S.; Chatzivassiliou, E.K. Virus Surveys in Olive Orchards in Greece Identify Olive Virus T, a Novel Member of the Genus Tepovirus. Pathogens 2021, 10, 574.

10. Martelli, G.P. Infectious diseases and certification of olive: An overview. EPPO Bull. 1999, 29, 127-133. [CrossRef]

11. Godena, S.; Bendini, A.; Giambanelli, E.; Cerretani, L.; Đermić, D.; Đermić, E. Cherry leafroll virus: Impact on olive fruit and virgin olive oil quality. Eur. J. Lipid Sci. Technol. 2012, 114, 535-541. [CrossRef]

12. Alabdullah, A.; Minafra, A.; Elbeaino, T.; Saponari, M.; Savino, V.; Martelli, G.P. Complete nucleotide sequence and genome organization of Olive latent virus 3, a new putative member of the family Tymoviridae. Virus Res. 2010, 152, 10-18. [CrossRef]

13. Rojas, M.R.; Macedo, M.A.; Maliano, M.R.; Soto-Aguilar, M.; Souza, J.O.; Briddon, R.W.; Kenyon, L.; Rivera Bustamante, R.F.; Zerbini, F.M.; Adkins, S.; et al. World Management of Geminiviruses. Annu. Rev. Phytopathol. 2015, 56, 637-677. [CrossRef]

14. Zerbini, F.M.; Briddon, R.W.; Idris, A.; Martin, D.P.; Moriones, E.; Navas-Castillo, J.; Rivera-Bustamante, R.; Roumagnac, P.; Varsani, A.; Consortium, I.R. ICTV Virus Taxonomy Profile: Geminiviridae. J. Gen. Virol. 2017, 98, 131-133. [CrossRef]

15. Hanley-Bowdoin, L.; Bejarano, E.R.; Robertson, D.; Mansoor, S. Geminiviruses: Masters at redirecting and reprogramming plant processes. Nat. Rev. Microbiol. 2013, 11, 777-788. [CrossRef] [PubMed]

16. ICTV. Available online: https://talk.ictvonline.org/taxonomy/ (accessed on 2 September 2021).

17. Ma, Y.; Navarro, B.; Zhang, Z.; Lu, M.; Zhou, X.; Chi, S.; Di Serio, F.; Li, S. Identification and molecular characterization of a novel monopartite geminivirus associated with mulberry mosaic dwarf disease. J. Gen. Virol. 2015, 96, 2421-2434. [CrossRef]

18. Saunders, K.; Salim, N.; Mali, V.R.; Malathi, V.G.; Briddon, R.; Markham, P.G.; Stanley, J. Characterisation of Sri Lankan cassava mosaic virus and Indian cassava mosaic virus: Evidence for acquisition of a DNA B component by a monopartite begomovirus. Virology 2002, 293, 63-74. [CrossRef] [PubMed]

19. Rojas, A.; Kvarnheden, A.; Marcenaro, D.; Valkonen, J.P.T. Sequence characterization of Tomato leaf curl Sinaloa virus and Tomato severe leaf curl virus: Phylogeny of New World begomoviruses and detection of recombination. Arch. Virol. 2005, 150, 1281-1299. [CrossRef]

20. Briddon, R.W.; Patil, B.L.; Bagewadi, B.; Nawaz-Ul-Rehman, M.S.; Fauquet, C.M. Distinct evolutionary histories of the DNA-A and DNA-B components of bipartite begomoviruses. BMC Evol. Biol. 2010, 10, 97. [CrossRef] [PubMed]

21. Melgarejo, T.A.; Kon, T.; Rojas, M.R.; Paz-Carrasco, L.; Zerbini, F.M.; Gilbertson, R.L. Characterization of a new world monopartite begomovirus causing leaf curl disease of tomato in Ecuador and Peru reveals a new direction in geminivirus evolution. J. Virol. 2013, 87, 5397-5413. [CrossRef] [PubMed]

22. Macedo, M.A.; Albuquerque, L.C.; Maliano, M.R.; Souza, J.O.; Rojas, M.R.; Inoue-Nagata, A.K.; Gilbertson, R.L. Characterization of tomato leaf curl purple vein virus, a new monopartite New World begomovirus infecting tomato in Northeast Brazil. Arch. Virol. 2018, 163, 737-743. [CrossRef]

23. Fondong, V.N. Geminivirus protein structure and function. Mol. Plant Pathol. 2013, 14, 635-649. [CrossRef]

24. Seal, S.E.; VandenBosch, F.; Jeger, M.J. Factors influencing begomovirus evolution and their increasing global significance: Implications for sustainable control. CRC. Crit. Rev. Plant Sci. 2006, 25, 23-46. [CrossRef]

25. Padidam, M.; Beachy, R.N.; Fauquet, C.M. The Role of AV2 ("Precoat") and Coat Protein in Viral Replication and Movement in Tomato Leaf Curl Geminivirus. Virology 1996, 224, 390-404. [CrossRef]

26. Rybicki, E.P. A phylogenetic and evolutionary justification for three genera of Geminiviridae. Arch. Virol. 1994, 139, 147-162. [CrossRef]

27. Ha, C.; Coombs, S.; Revill, P.; Harding, R.; Vu, M.; Dale, J. Molecular characterization of begomoviruses and DNA satellites from Vietnam: Additional evidence that the New World geminiviruses were present in the Old World prior to continental separation. $J$. Gen. Virol. 2008, 89, 312-326. [CrossRef] [PubMed]

28. Argüello-Astorga, G.R.; Guevara-González, R.G.; Herrera-Estrella, L.R.; Rivera-Bustamante, R.F. Geminivirus Replication Origins Have a Group-Specific Organization of Iterative Elements: A Model for Replication. Virology 1994, 203, 90-100. [CrossRef]

29. Fontes, E.P.B.; Gladfelter, H.J.; Schaffer, R.L.; Petty, I.T.D.; Hanley-Bowdoin, L. Geminivirus replication origins have a modular organization. Plant Cell 1994, 6, 405-416. [CrossRef] [PubMed]

30. Fontes, E.P.B.; Eagle, P.A.; Sipe, P.S.; Luckow, V.A.; Hanley-Bowdoin, L. Interaction between a geminivirus replication protein and origin DNA is essential for viral replication. J. Biol. Chem. 1994, 269, 8459-8465. [CrossRef]

31. Singh, J. Role of DNA replication in establishment and propagation of epigenetic states of chromatin. Semin. Cell Dev. Biol. 2014, 30, 131-143. [CrossRef] [PubMed]

32. Briddon, R.O.B.W.; Bedford, I.A.N.D.; Tsai, J.H.; Markham, P.G. Analysis of the Nucleotide Sequence of the TreehopperTransmitted Geminivirus, Tomato Pseudo-Curly Top Virus, Suggests a Recombinant Origin. Virology 1996, 219, 387-394. [CrossRef] 
33. Bolger, A.M.; Lohse, M.; Usadel, B. Trimmomatic: A flexible trimmer for Illumina sequence data. Bioinformatics 2014, 30, 2114-2120. [CrossRef] [PubMed]

34. Langmead, B.; Salzberg, S.L. Fast gapped-read alignment with Bowtie 2. Nat. Methods 2012, 9, 357-359. [CrossRef] [PubMed]

35. Grabherr, M.G.; Haas, B.J.; Yassour, M.; Levin, J.Z.; Thompson, D.A.; Amit, I.; Adiconis, X.; Fan, L.; Raychowdhury, R.; Zeng, Q.; et al. Full-length transcriptome assembly from RNA-Seq data without a reference genome. Nat. Biotechnol. 2011, $29,644-652$. [CrossRef]

36. Benson, D.A.; Cavanaugh, M.; Clark, K.; Karsch-Mizrachi, I.; Lipman, D.J.; Ostell, J.; Sayers, E.W. GenBank. Nucleic Acids Res. 2013, 41, D36-D42. [CrossRef] [PubMed]

37. Kumar, S.; Stecher, G.; Li, M.; Knyaz, C.; Tamura, K. MEGA X: Molecular Evolutionary Genetics Analysis across Computing Platforms. Mol. Biol. Evol. 2018, 35, 1547-1549. [CrossRef] [PubMed]

38. Gasteiger, E.; Hoogland, C.; Gattiker, A.; Duvaud, S.; Wilkins, M.; Appel, R.; Bairoch, A. Protein Identification and Analysis Tools on the ExPASy Server. In The Proteomics Protocols Handbook; Walker, J.M., Ed.; Humana Press: Totowa, NJ, USA, 2005; Volume 52, pp. 571-607.

39. Muhire, B.M.; Varsani, A.; Martin, D.P. SDT: A virus classification tool based on pairwise sequence alignment and identity calculation. PLoS ONE 2014, 9, e0108277. [CrossRef] [PubMed]

40. Martin, D.P.; Murrell, B.; Golden, M.; Khoosal, A.; Muhire, B. RDP4: Detection and analysis of recombination patterns in virus genomes. Virus Evol. 2015, 1. [CrossRef] [PubMed]

41. Chakraborty, A.; Mandloi, S.; Lanczycki, C.J.; Panchenko, A.R.; Chakrabarti, S. SPEER-SERVER: A web server for prediction of protein specificity determining sites. Nucleic Acids Res. 2012, 40, W242-W248. [CrossRef]

42. Brown, D.P.; Krishnamurthy, N.; Sjölander, K. Automated protein subfamily identification and classification. PLoS Comput. Biol. 2007, 3, e160. [CrossRef]

43. Alabi, O.J.; Diaz-Lara, A.; Erickson, T.M.; Al Rwahnih, M. Olea europaea geminivirus is present in a germplasm repository and in California and Texas olive (Olea europaea L.) groves. Arch. Virol. 2021, 1-6. [CrossRef]

44. Harrison, B.D.; Swanson, M.M.; Fargette, D. Begomovirus coat protein: Serology, variation and functions. Physiol. Mol. Plant Pathol. 2002, 60, 257-271. [CrossRef]

45. Wylie, S.J.; Li, H.; Saqib, M.; Jones, M.G.K. The Global Trade in Fresh Produce and the Vagility of Plant Viruses: A Case Study in Garlic. PLoS ONE 2014, 9, e105044. [CrossRef]

46. Jo, Y.; Choi, H.; Kim, S.-M.; Kim, S.-L.; Lee, B.C.; Cho, W.K. The pepper virome: Natural co-infection of diverse viruses and their quasispecies. BMC Genom. 2017, 18, 453. [CrossRef]

47. Coetzee, B.; Freeborough, M.-J.; Maree, H.J.; Celton, J.-M.; Rees, D.J.G.; Burger, J.T. Deep sequencing analysis of viruses infecting grapevines: Virome of a vineyard. Virology 2010, 400, 157-163. [CrossRef]

48. Jo, Y.; Choi, H.; Kyong Cho, J.; Yoon, J.-Y.; Choi, S.-K.; Kyong Cho, W. In silico approach to reveal viral populations in grapevine cultivar Tannat using transcriptome data. Sci. Rep. 2015, 5, 15841. [CrossRef]

49. Matsumura, E.E.; Coletta-Filho, H.D.; Nouri, S.; Falk, B.W.; Nerva, L.; Oliveira, T.S.; Dorta, S.O.; Machado, M.A. Deep Sequencing Analysis of RNAs from Citrus Plants Grown in a Citrus Sudden Death-Affected Area Reveals Diverse Known and Putative Novel Viruses. Viruses 2017, 9, 92. [CrossRef]

50. Torres-Herrera, S.I.; Romero-Osorio, A.; Moreno-Valenzuela, O.; Pastor-Palacios, G.; Cardenas-Conejo, Y.; Ramírez-Prado, J.H.; Riego-Ruiz, L.; Minero-García, Y.; Ambriz-Granados, S. A lineage of begomoviruses encode rep and AC4 proteins of enigmatic ancestry: Hints on the evolution of geminiviruses in the newworld. Viruses 2019, 11, 644. [CrossRef] [PubMed]

51. Ho, E.S.; Kuchie, J.; Duffy, S. Bioinformatic analysis reveals genome size reduction and the emergence of tyrosine phosphorylation site in the movement protein of new world bipartite begomoviruses. PLoS ONE 2014, 9, e111957. [CrossRef] [PubMed]

52. Hipp, K.; Rau, P.; Schäfer, B.; Pfannstiel, J.; Jeske, H. Translation, modification and cellular distribution of two AC4 variants of African cassava mosaic virus in yeast and their pathogenic potential in plants. Virology 2016, 498, 136-148. [CrossRef] [PubMed]

53. Carluccio, A.V.; Prigigallo, M.I.; Rosas-Diaz, T.; Lozano-Duran, R.; Stavolone, L. S-acylation mediates Mungbean yellow mosaic virus AC4 localization to the plasma membrane and in turns gene silencing suppression. PLOS Pathog. 2018, 14 , e1007207. [CrossRef] [PubMed]

54. Fondong, V.N.; Reddy, R.V.C.; Lu, C.; Hankoua, B.; Felton, C.; Czymmek, K.; Achenjang, F. The Consensus N-Myristoylation Motif of a Geminivirus AC4 Protein Is Required for Membrane Binding and Pathogenicity. Mol. Plant-Microbe Interact. 2007, 20, 380-391. [CrossRef] [PubMed]

55. Mills-Lujan, K.; Deom, C.M. Geminivirus C4 protein alters Arabidopsis development. Protoplasma 2010, 239, 95-110. [CrossRef] [PubMed]

56. Mei, Y.; Wang, Y.; Hu, T.; Yang, X.; Lozano-Duran, R.; Sunter, G.; Zhou, X. Nucleocytoplasmic Shuttling of Geminivirus C4 Protein Mediated by Phosphorylation and Myristoylation Is Critical for Viral Pathogenicity. Mol. Plant 2018, 11, 1466-1481. [CrossRef]

57. Módena, N.A.; Zelada, A.M.; Conte, F.; Mentaberry, A. Phosphorylation of the TGBp1 movement protein of Potato virus X by a Nicotiana tabacum CK2-like activity. Virus Res. 2008, 137, 16-23. [CrossRef] [PubMed]

58. Rothenstein, D.; Krenz, B.; Selchow, O.; Jeske, H. Tissue and cell tropism of Indian cassava mosaic virus (ICMV) and its AV2 (precoat) gene product. Virology 2007, 359, 137-145. [CrossRef] 
59. Glick, E.; Zrachya, A.; Levy, Y.; Mett, A.; Gidoni, D.; Belausov, E.; Citovsky, V.; Gafni, Y. Interaction with host SGS3 is required for suppression of RNA silencing by tomato yellow leaf curl virus V2 protein. Proc. Natl. Acad. Sci. USA 2008, 105, 157-161. [CrossRef]

60. Choi, I.-R.; Stenger, D.C. The Strain-Specificcis-Acting Element of Beet Curly Top Geminivirus DNA Replication Maps to the Directly Repeated Motif of theOri. Virology 1996, 226, 122-126. [CrossRef]

61. Chatterji, A.; Chatterji, U.; Beachy, R.N.; Fauquet, C.M. Sequence parameters that determine specificity of binding of the replication-associated protein to its cognate site in two strains of tomato leaf curl virus-New Delhi. Virology 2000, 273, 341-350. [CrossRef]

62. Sudarshana, M.R.; Wang, H.L.; Lucas, W.J.; Gilbertson, R.L. Dynamics of bean dwarf mosaic geminivirus cell-to-cell and longdistance movement in Phaseolus vulgaris revealed, using the green fluorescent protein. Mol. Plant-Microbe Interact. 1998, 11, 277-291. [CrossRef]

63. Rojas, M.R.; Jiang, H.; Salati, R.; Xoconostle-Cázares, B.; Sudarshana, M.R.; Lucas, W.J.; Gilbertson, R.L. Functional analysis of proteins involved in movement of the monopartite begomovirus, Tomato yellow leaf curl virus. Virology 2001, 291, 110-125. [CrossRef]

64. Liu, H.; Andrew; Lucy, P.; Davies, J.W.; Boulton, M.I. A single amino acid change in the coat protein of Maize streak virus abolishes systemic infection, but not interaction with viral DNA or movement protein. Mol. Plant Pathol. 2001, 2, 223-228. [CrossRef] [PubMed]

65. Varanda, C.M.R.; Nolasco, G.; Clara, M.I.; Félix, M.R. Genetic diversity of the coat protein of olive latent virus 1 isolates. Arch. Virol. 2014, 159, 1351-1357. [CrossRef] [PubMed]

66. Varanda, C.M.R.; Machado, M.; Martel, P.; Nolasco, G.; Clara, M.I.E.; Félix, M.R. Genetic diversity of the coat protein of olive mild mosaic virus (OMMV) and tobacco necrosis virus D (TNV-D) isolates and its structural implications. PLoS ONE 2014, 9, e110941. [CrossRef] [PubMed]

67. Varanda, C.M.R.; Materatski, P.; Campos, M.D.; Clara, M.I.E.; Nolasco, G.; Félix, M.D.R. Olive mild mosaic virus coat protein and P6 are suppressors of RNA silencing, and their silencing confers resistance against OMMV. Viruses 2018, 10, 416. [CrossRef] [PubMed]

68. Boulton, M.I.; King, D.I.; Markham, P.G.; Pinner, M.S.; Davies, J.W. Host range and symptoms are determined by specific domains of the maize streak virus genome. Virology 1991, 181, 312-318. [CrossRef]

69. Varanda, C.; Félix, M.d.R.; Soares, C.M.; Oliveira, S.; Clara, M.I. Specific amino acids of Olive mild mosaic virus coat protein are involved in transmission by Olpidium brassicae. J. Gen. Virol. 2011, 92, 2209-2213. [CrossRef]

70. Varanda, C.M.R.; Silva, M.S.M.R.; Félix, M.D.R.F.; Clara, M.I.E. Evidence of olive mild mosaic virus transmission by Olpidium brassicae. Eur. J. Plant Pathol. 2011, 130, 165-172. [CrossRef]

71. Rosario, K.; Seah, Y.M.; Marr, C.; Varsani, A.; Kraberger, S.; Stainton, D.; Moriones, E.; Polston, J.E.; Duffy, S.; Breitbart, M. Vector-Enabled Metagenomic (VEM) Surveys Using Whiteflies (Aleyrodidae) Reveal Novel Begomovirus Species in the New and Old Worlds. Viruses 2015, 7, 5553-5570. [CrossRef]

72. Inoue-Nagata, A.K.; Lima, M.F.; Gilbertson, R.L. A review of geminivirus diseases in vegetables and other crops in Brazil: Current status and approaches for management. Hortic. Bras. 2016, 34, 8-18. [CrossRef] 